\title{
Context Matters: Pliny's Phryges and the Basilica Paulli in Rome
}

\author{
Rolf Michael Schneider
}

Three years with Anthony in Cambridge (I998-200I), at and beyond the Faculty of Classics, have left a profound impression on me. Remembering vivid debates with him I will here ride a hobby horse that both of us share. It concerns the multiple relationship and reading of image, text and context or, in other words, art, archaeology, philology and history. By tackling this, I will re-open an issue touched upon in my book Bunte Barbaren ( 1986 : I I 5-25). My argument is twofold: one strand is the archaeology of the Basilica Paulli (for the name, see below), built on the Forum Romanum in Rome; ${ }^{1}$ the other is a misread passage in Pliny's Natural History (XXXVI.IO2) on this building. I will begin my study as an archaeologist and art historian who examines the architecture, sculpture and history of the Basilica Paulli. Next, I will become a philologist who analyses Pliny's passage within its textual tradition and reading of Classical scholarship. Then I will confront the outcome of both and discuss concurrences, differences and blind spots. Finally, I will sketch out a historical framework, which is based not on the deficient premise of the intentional reading, but on the practice of intentional readings within the wider context of 'intentionaler Geschichte' (Gehrke 20I4: 9-36). Before I go on, however, I need to clarify a problem of terminology. Whenever I speak of statues of Asians and Asian dress, I refer not to all peoples of Asia but to those of Asia Minor and the Near East.

\section{Archaeology and history}

In the nineteenth century, remains on the north-eastern side of the Forum Romanum were identified as belonging to the Basilica Paulli (Chioffi I996: 34-5; Fig. I7.I 8 below), which had been situated opposite the Basilica Iulia. This identification had been based on ancient texts which are, however, ambiguous in their reading. They attest in the Forum Romanum either a single Basilica Fulvia-Aemilia-Paulli (communis opinio) or two separate basilicas, namely an archaeologically unverified Basilica Aemilia and the verified Basilica Fulvia-Paulli. The latter is here called the Basilica Paulli and not the Basilica Aemilia, which is what, confusingly, most scholars have called it. $^{2}$ In I 993 Eva Margareta Steinby scrutinised the opposing 
statements again and concluded that only the assumption of two separate basilicas, set up in the Forum Romanum in two different areas, would resolve the contradictions in the texts. ${ }^{3}$ This, however, is not as obvious as she has argued it to be. The different names and locations depend, at least in some part, on the choices and objectives of the individual writers who mention the above basilica(s) while pursuing their own agenda, and who do not have an academic interest in being accurate as to name and location. These inconsistencies and the lack of verifiable archaeological remains of a separate 'Basilica Aemilia' do not endorse the unambiguous reading Steinby has proposed. I will omit this problem here, as it cannot be resolved and does not affect my argument in a serious manner. More specific than the texts are the archaeological remains of the Basilica Paulli found in this area of the Forum Romanum, as we will see below.

The excavations of the Basilica Paulli began in I 898 (Figs. I7.I-I7.2). ${ }^{4}$ The essential spadework was done by Giacomo Boni (I898-I905) 5 and was continued by Alfonso Bartoli (until I939), ${ }^{6}$ then by Gianfilippo Carettoni (I946-8) 7 and Riccardo Gamberini Mongenet (I950-4). ${ }^{8}$ As a result of this evidence and more than twenty years of painstaking research (1970-90s) Heinrich Bauer, a Classical archaeologist with substantial architectural knowledge, proposed a new reconstruction of the basilica and its chronology in the early imperial period (Fig. I 7.3).9 Around the same time Laura Fabbrini started to investigate the numerous sculptural fragments found inside the basilica by Boni and Bartoli. ${ }^{10}$ In collaboration

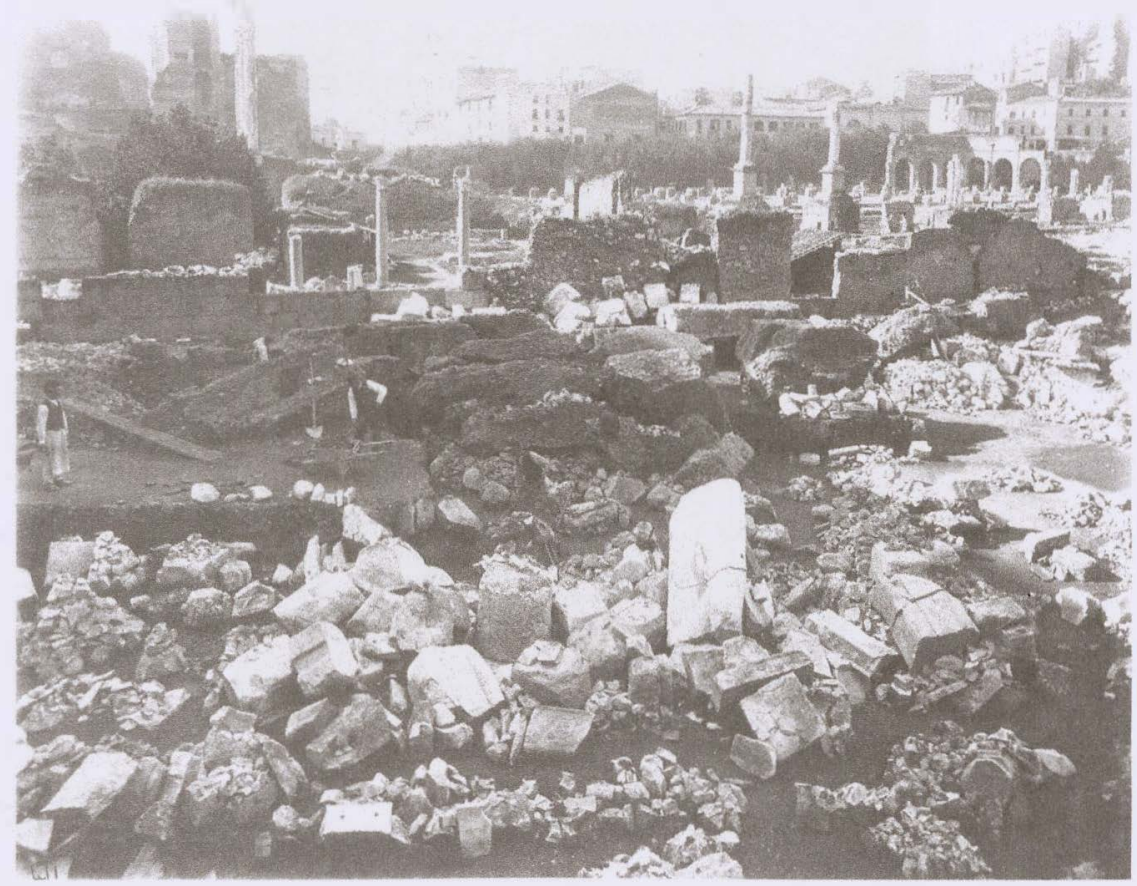

Figure 17.1 Rome, Basilica Paulli, from the east. Excavation of Giacomo Boni, c. 1900. Rome. DAI, Heide Behrens: 2014.1082. 


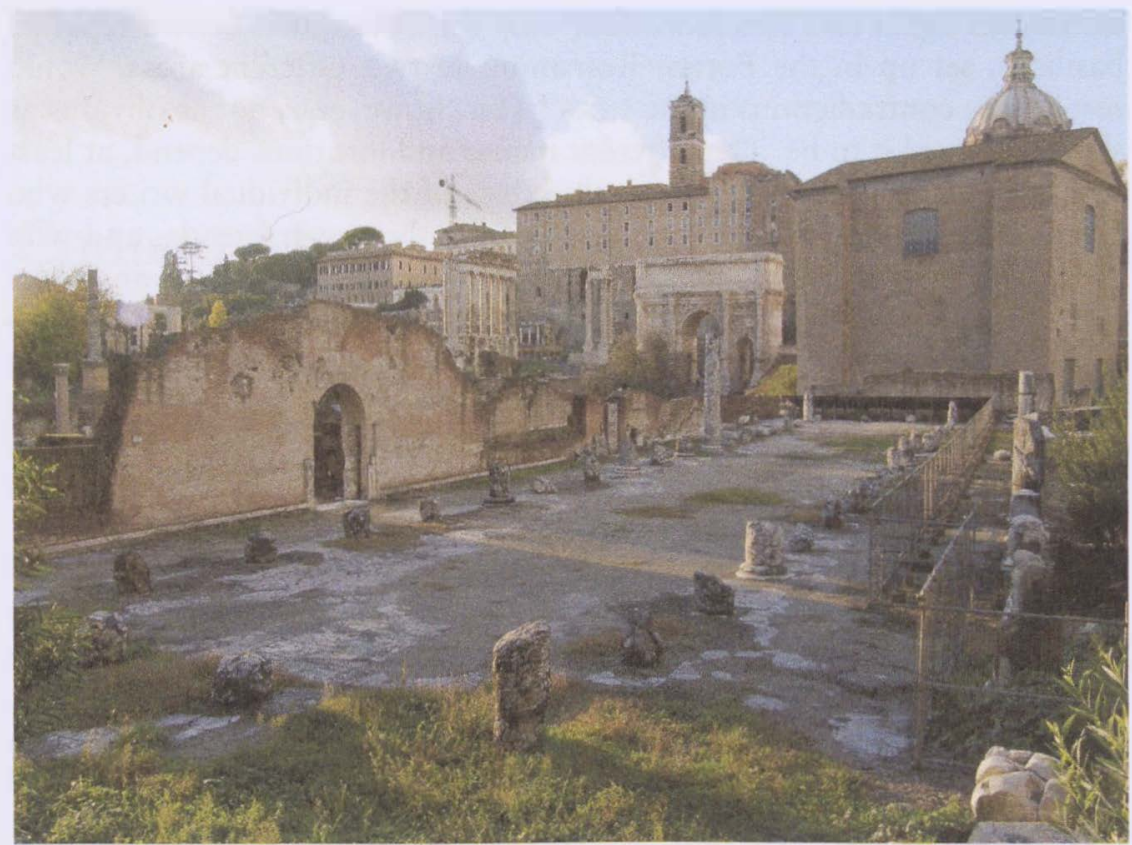

Figure 17.2 Rome, Basilica Paulli, from the east. 2007. Rome. DAI, Heide Behrens: 2007-1072.

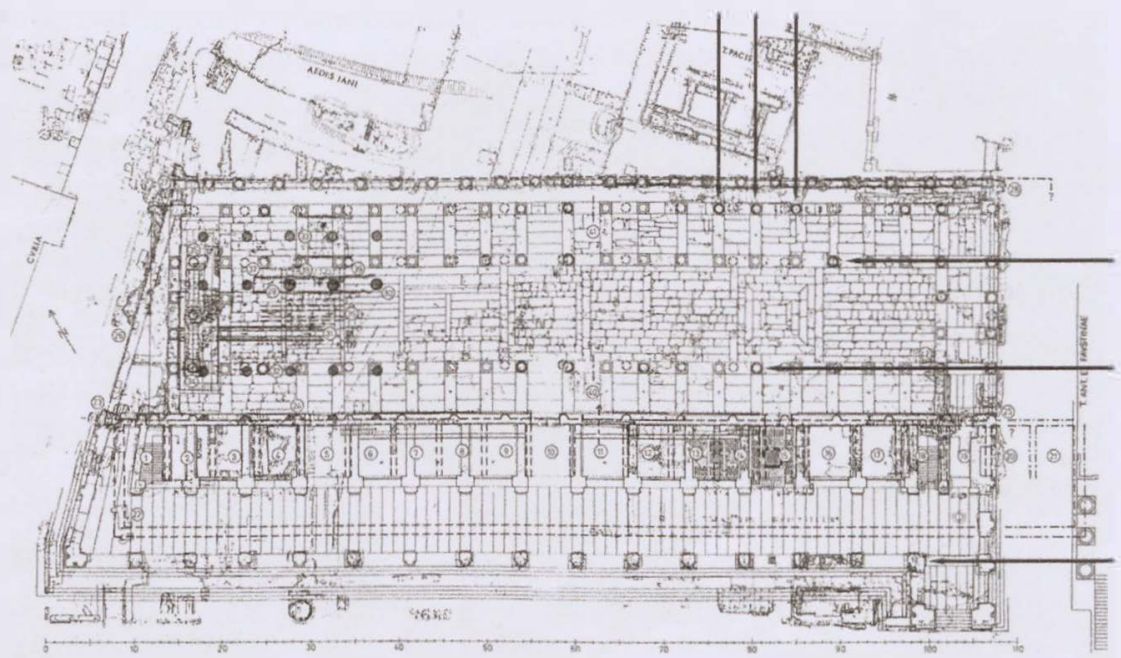

Figure 17.3 Rome, Basilica Paulli. Ground plan (Heinrich Bauer, 1970s; revised by Johannes Lipps, 2012). After 14 BC. Tübingen. Johannes Lipps. 
with Heinrich Bauer she established a large series of over-life-sized statues (height c. 2.3-2.4 m) depicting foreigners in Asian dress and sculpted mainly in marmor Phrygium (Fig. 17.4). ${ }^{11}$ Both scholars assigned them stylistically to the period of Augustus. They also identified the statues' pedestals, made of white marble (width $84-94 \mathrm{~cm}$, height $72-6 \mathrm{~cm}$,

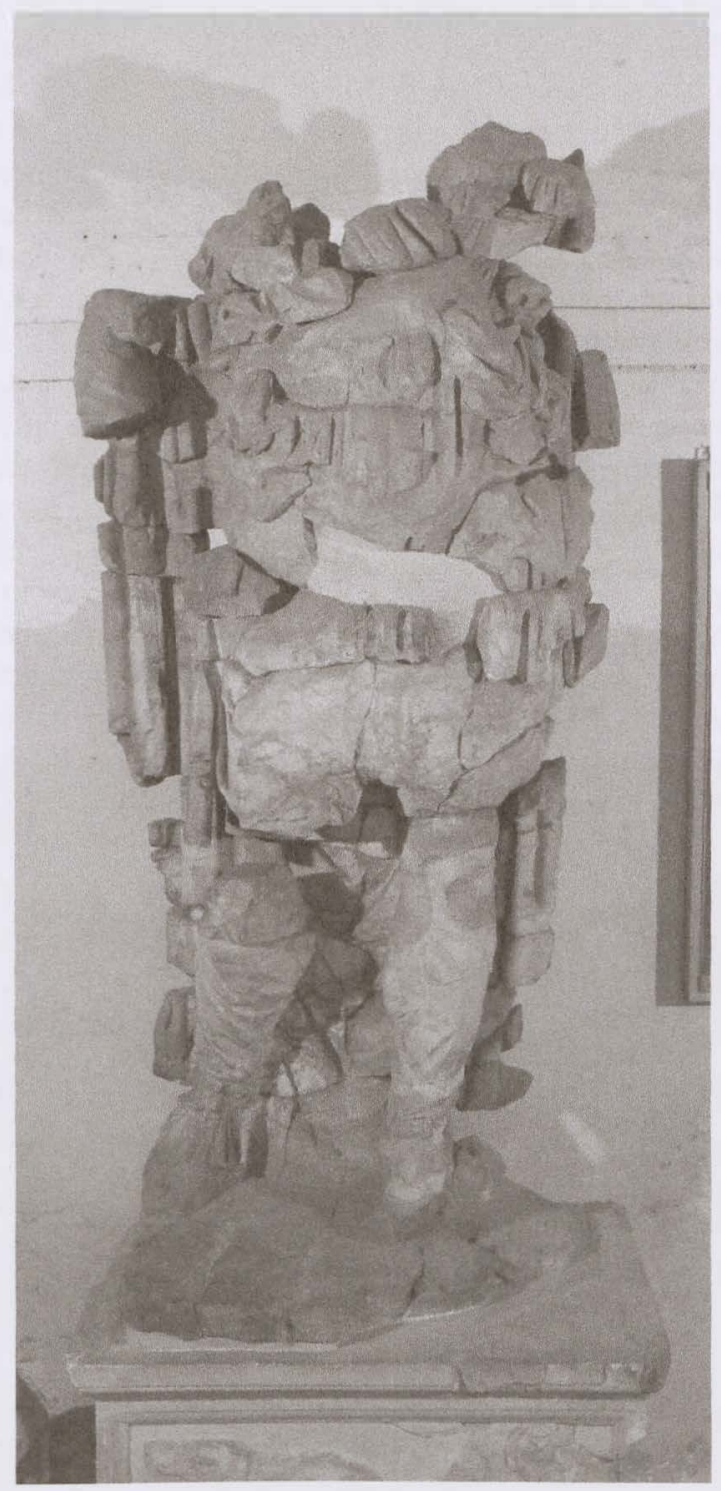

Figure 17.4 Rome, Antiquario Forense. Reconstruction: handsome Asian statue (Laura Fabbrini and Heinrich Baner, 1970s). After 14 BC. Rome. DAI, Heide Behrens: 2007.1812. 
depth 64-6 cm), adorned on the front and the two shorter sides with subtly arranged tendrils (Fig. I7.5a-b). Finally, Fabbrini and Bauer linked eighteen heads in white marble to the statues and fitted one of these heads into a well-preserved Phrygian cap, which had been carved from the same block of Phrygian marble as one of the statues (Figs. I 7.6-I 7.7). The heads show handsome, clean-shaven faces framed by rich locks. Many heads preserve traces of ancient colouring. Bauer read the statues as representations of Parthians holding with raised arm a Roman standard (Fig. I 7.8), ${ }^{12}$ which refers to the well over a hundred lost to them by Roman armies beginning in $53 \mathrm{BC}$ and eventually regained by Rome in $20 \mathrm{BC}$ (Schneider 20 I 2: I I 2-I9). Regrettably, none of these scholars published their studies.

In I980 I was allowed to investigate the remains of the basilica's statues set up in Rome's Antiquario Forense, but was denied access to the storerooms and was not given permission to publish the sculptures. ${ }^{13}$ On the basis of the accessible fragments I suggested a new reconstruction for the statues, namely with a raised arm in a pose of structural support, and, subsequently, argued in favour of an architectonic and symbolic function (see Fig. I7.13 below). I understood them, then too one-sidedly, to be idealised portrayals of subdued Parthians conceived in the aftermath of $20 \mathrm{BC}$ and related to the so-called settlement of the Parthian question. In 2005 Stefan Freyberger and Christine Ertel initiated the 'Basilica Aemilia Project'. In collaboration with the German Archaeological Institute at Rome they aimed to present a systematic review of the unpublished data; a detailed architectural survey of the remains in situ; a new reconstruction (Figs 17.9-17.IO) and reading of the basilica in its historical context (preliminary report by Freyberger and
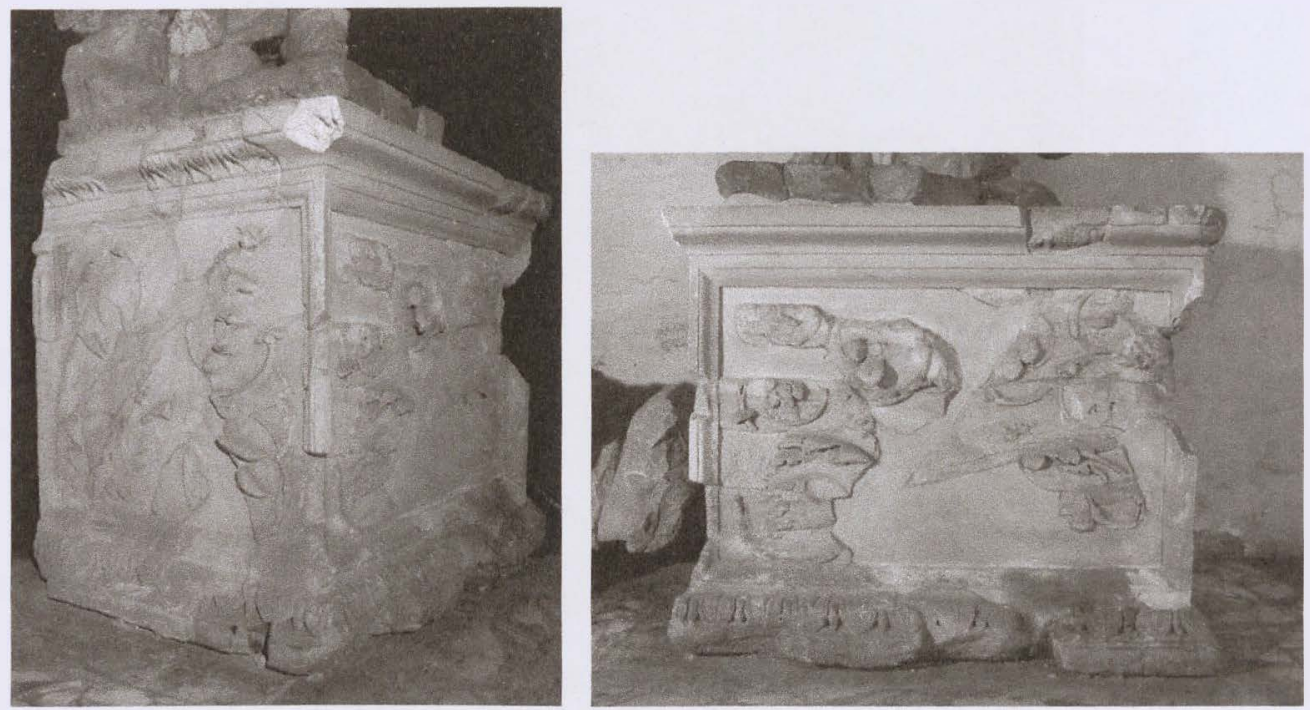

Figure 17.5a-b Rome, Antiquario Forense. Reconstruction: pedestal of a handsome Asian statue (Laura Fabbrini and Heinrich Baner, 1970s). After 14 BC. Rome. DAI, Heide Bebrens: 2007.2008 and 2007.2010. 


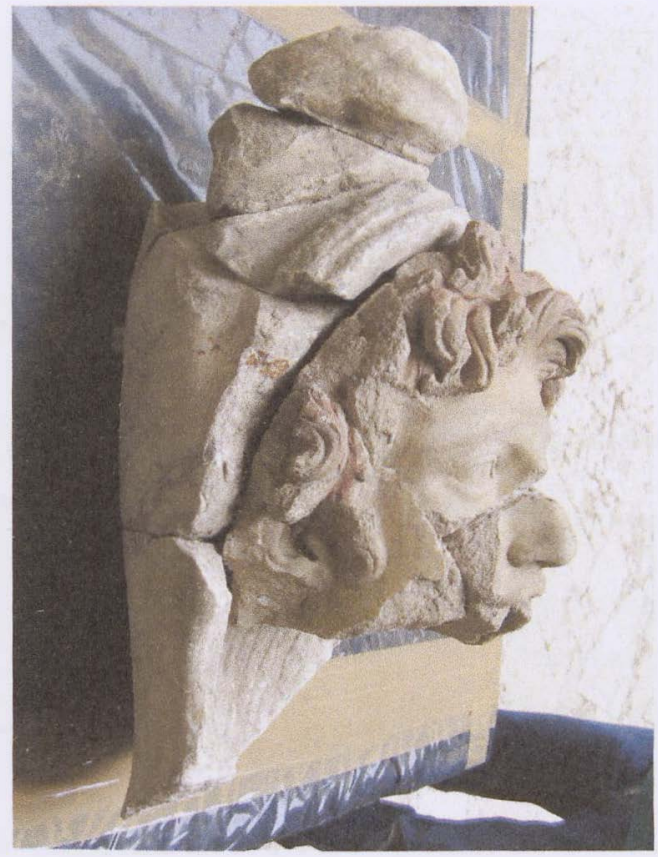

Figure 17.6 Rome, Antiquario Forense. Handsome Asian head. After 14 BC. Ravensburg. Tobias Bitterer.

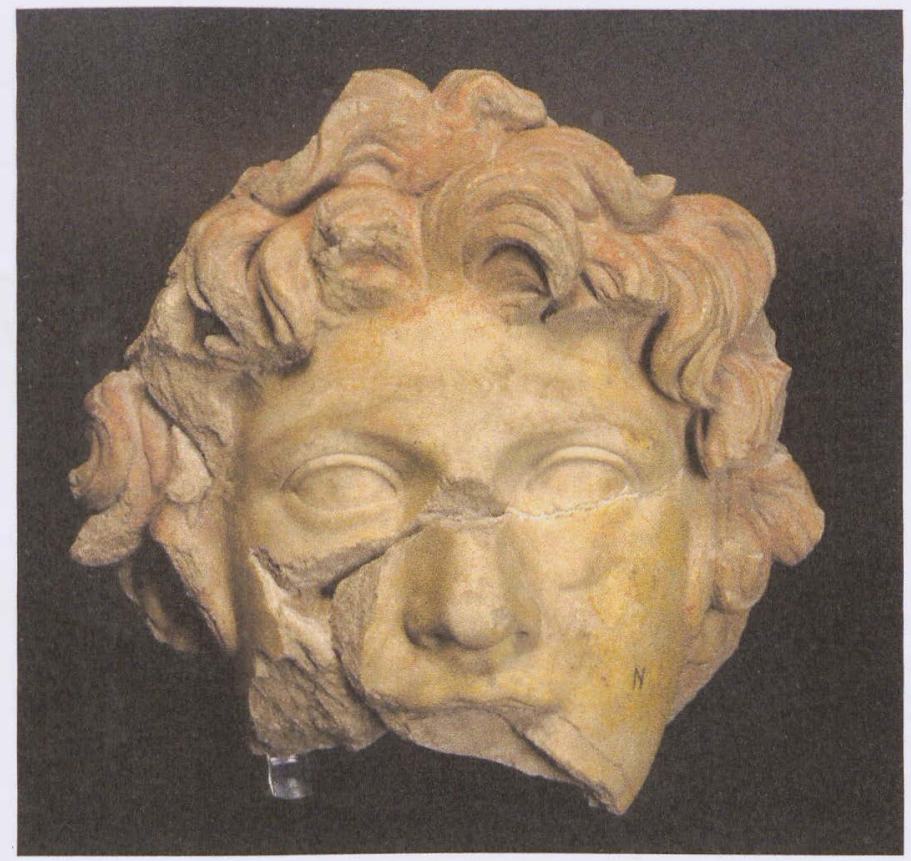

Figure 17.7 Rome, Antiquario Forense. Handsome Asian head. After 14 BC. Rome. DAI, Heide Behrens: 2007.6871. 


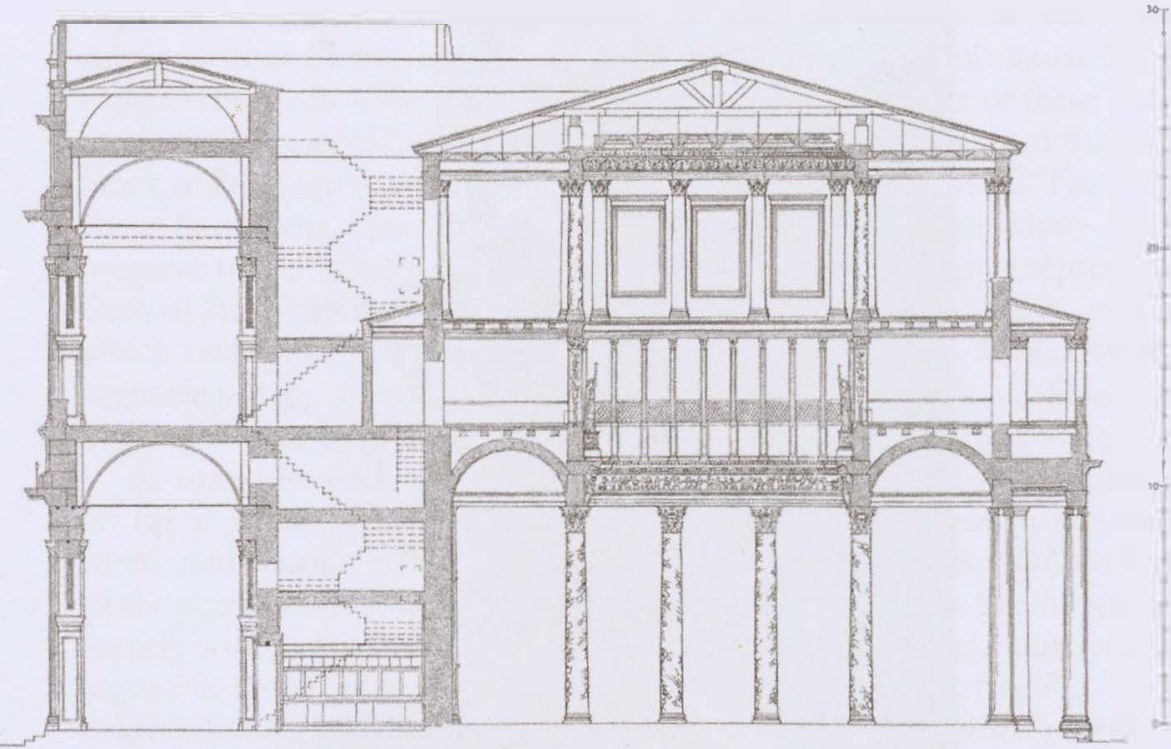

Figure 17.8 Rome, Basilica Paulli. Cross-section, from the south-east (Heinrich Baner, 1970s). After 14 BC. Tübingen. Johannes Lipps.

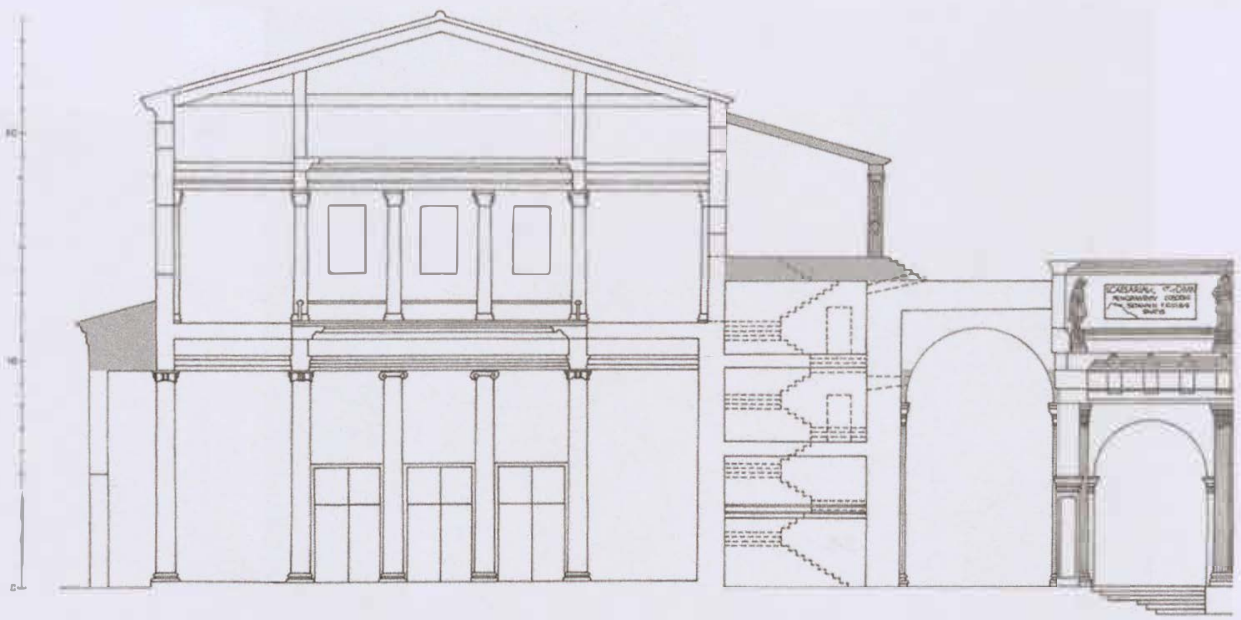

Figure 17.9 Rome, Basilica Paulli. Cross-section, from the north-west (Christine Ertel and Stefan Freyberger, 2007). After 14 BC. Tübingen. Johannes Lipps. 


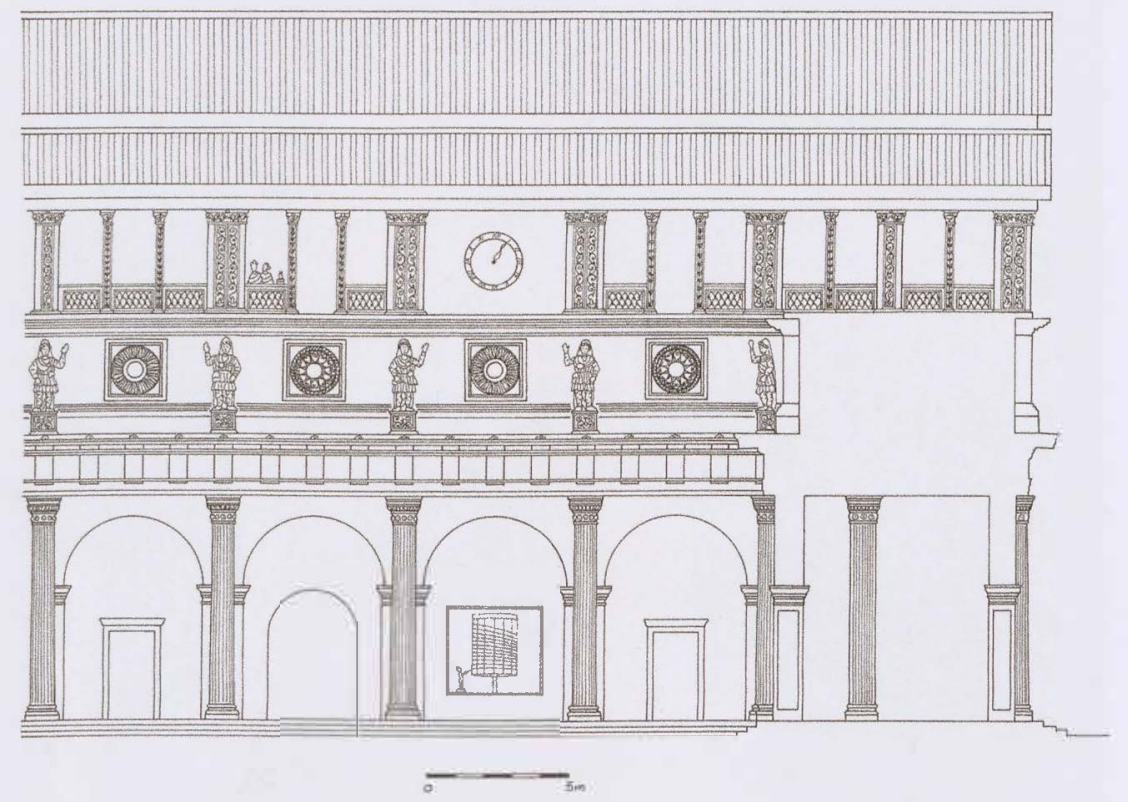

Figure 17.10 Rome, Basilica Paulli. Reconstruction: façade (Christine Ertel and Stefan Freyberger, 2007). After 14 BC. Tübingen. Johannes Lipps

Ertel 2007). Two Classical archaeologists from Munich joined this project: Johannes Lipps to examine the architectural décor and Tobias Bitterer to study the handsome Asians. From a mass of some ten thousand fragments of architectural décor, Lipps (201 I) singled out I,877 pieces, which he linked to the basilica. In allocating 953 pieces to their original setting, he contributed profoundly to the basilica's reconstruction and reading. ${ }^{14}$ Tobias Bitterer (2007), on the other hand, scrutinised 7I 8 surviving fragments of the handsome Asians. He confirmed the assumptions proposed in 1986 , namely the reconstruction of the raised arm, the architectonic function of the statues and their stylistic dating to the period of Augustus. Bitterer presented in his preliminary report the most essential fragments of the statues including one of their spectacular heads (Figs. 17.6-17.7 above) and a right hand (Fig. 17.I I). For the first time, the architectural décor and the key fragments of the Asian statues became widely accessible to scholarship.

The above research produced evidence of three main building phases: deep in the ground, two earlier structures including remains of column settings attributable to but not precisely datable within the Hellenistic period of Rome; and, above these structures, the layout of the basilica built in the period of Augustus. As a consequence, the first two building phases cannot be neatly linked to the major building activities in the second and first century BC as mentioned by ancient authors. ${ }^{\text {Is }}$ The conflicting texts hand down (Lipps 20II: I7-27): a first construction of the basilica by 


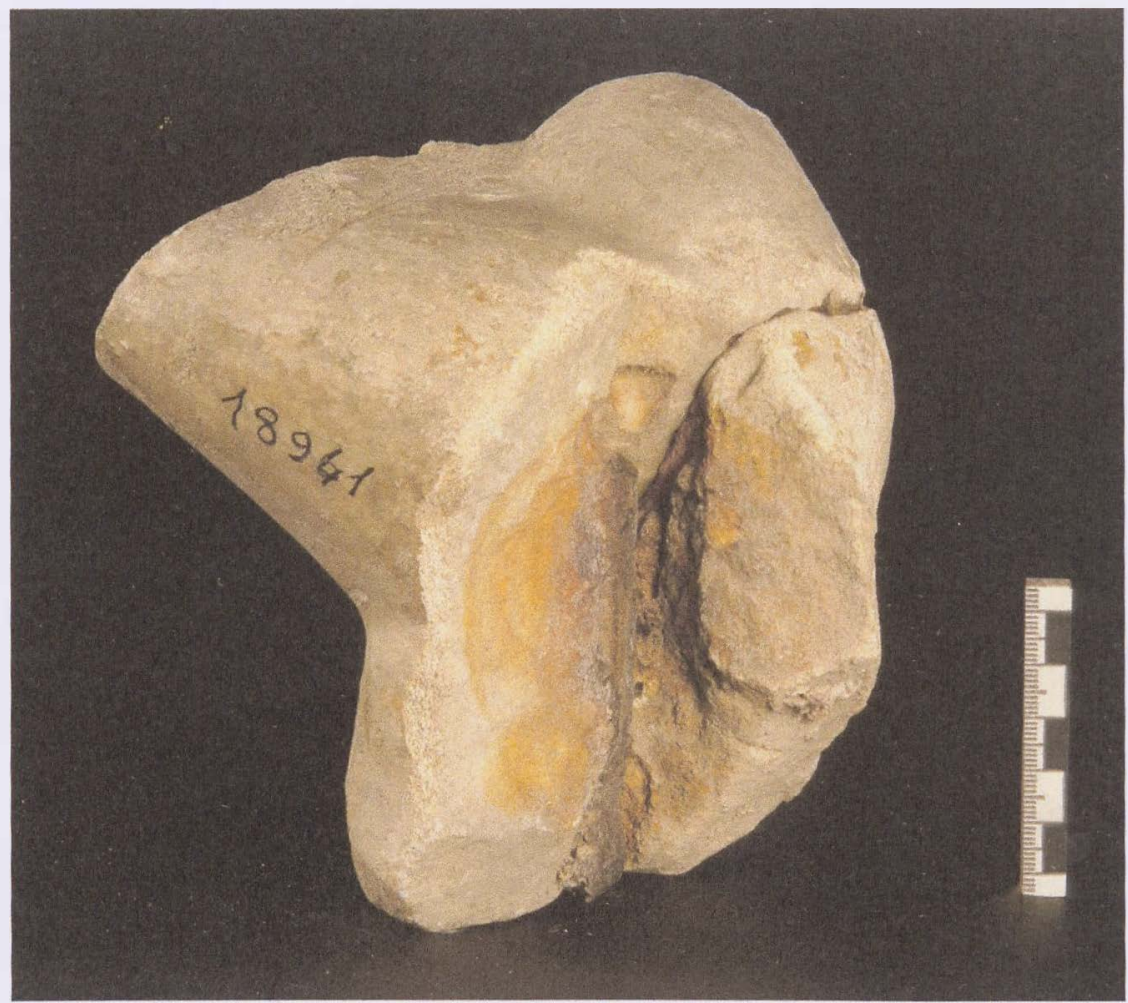

Figure 17.11 Rome, Antiquario Forense. Fragment: right hand of a handsome Asian statue. After 14 BC. Rome. DAI, Heide Behrens: 2007.2765.

M. Fulvius Nobilior (and M. Aemilius Lepidus?) in I79 BC; the installation of a water clock in $\mathrm{I} 59 \mathrm{BC}$; the attachment of imagines clipeati in the basilica's interior in $78 \mathrm{BC}$, portraying the ancestors of $\mathrm{M}$. Aemilius Lepidus - also attested by denarii minted by his son in Rome (c. 6I-58 BC) which show a double-storey basilica with double-storey colonnades; ${ }^{16}$ the construction of a new building around the middle of the first century $\mathrm{BC}$, financed by the Aemilii Paulli and/or Caesar, and inaugurated in 34 BC; a drastic re-building of the basilica financed by M. Aemilius Paullus, his friends and Augustus after a fire in I4 BC (Fig. I7.3 above); and a renovation of the Augustan building in $A D$ 22, which has not yet been identified by the archaeological records (Lipps 20I I: I9). Looking back, it has become evident that both the archaeology and the history of the Basilica Paulli are complex and, despite substantial progress within the last forty years, dogged by unsolved or unsolvable problems. But it has also become clear that the Basilica Paulli played a key role in the development of the design of the Roman basilica.

I will now focus more closely on the basilica mentioned by Pliny (Nat. Hist. XXXVI.ro2). This is essentially the building constructed after I4 $\mathrm{BC}$, a date now established by thorough research into the archaeological, 
architectonic and decorative evidence. ${ }^{17}$ The Augustan basilica was a most advanced building (Figs. I 7.3 and I 7.8-1 7.IO above), measuring from west to east $94.10 \mathrm{~m}$ in length and from north to south $25.65 \mathrm{~m}$ in width (Lipps 20I I: 35). The space was divided by a long central nave, nave aisles on all four sides and a smaller, additional nave aisle in the north. The edifice was (at least) two storeys high. The central nave was supported by a two-storey colonnade, Ionic on the lower and Corinthian on the upper level. The floor and walls of the main naves had been lavishly veneered with white marble from Luna and mottled marbles of distinct colours: yellow-coloured marmor Numidicum; multicoloured marmor Luculleum, distinguished by its areas of red, beige, white and grey; whitish marmor Phrygium, veined with violet and crimson breccia; green-and-white-veined marmor Carystium; and pink and grey portasanta. ${ }^{18}$ The monolithic columns of the basilica were made of marmor Luculleum (lower colonnade) and marmor Carystium (upper colonnade). They were all smoothly polished and literally highlighted the extensive colouring of the naves. Whereas the interior had been designed in the very latest fashion of Roman architecture and material, the exterior was arranged in a more antiquated style and uniformly clad in white marble as a separate and (probably) single-storey portico of arches, decorated with half-columns and crowned with a high attic (Lipps 20II: 82-I 27). Overall the façade displayed an unconventional arrangement of Tuscan, Doric and Ionic styles. In short, the edifice stood out with its exceptional design, decoration, craftsmanship and (coloured) marble. Even though these features have been generally accepted, the architectural reconstruction of the upper parts of the Augustan basilica is still the subject of controversial debate (Figs. I7.8-I7.IO above). ${ }^{19}$ I will come back to this later.

\section{Handsome Asians}

To the present day 7 I 8 fragments of statues of over-lif-size have been found, mostly inside the basilica, including eighteen heads (Figs. I 7.6-I 7.7 above) and one rather well-preserved right hand (Fig. I7.I I above). ${ }^{20}$ The fragments testify to a minimum of eighteen over-life-sized statues of standing Asians measuring about 2.3-2.4 $\mathrm{m}$ in height. The clothed parts of the statues had been sculpted in one block of coloured marble, mostly in marmor Phrygium, but some also in marmor Numidicum. Heads and hands were separately carved in white marble and originally attached to the body, as in the statue of Ganymede in Sperlonga (Fig. 17.16 below). ${ }^{21}$ The Asian statues show the same weighted stance and the rich Asian dress: soft shoes, long trousers, a double-belted tunic, a long mantle covering the back and the Phrygian cap (Fig. I7.4 above and Fig. I7.I2). Unique in Greek and Roman art, however, is the extravagant combination of a short-sleeved tunic and a new, long-sleeved undergarment. The hair and skin of the cleanshaven faces show intense traces of the original colouring (Figs. I7.6-I7.7 above). The handsome faces are framed by long, opulent locks similar to those of mythical figures from Asia Minor, such as Attis, Ganymede 


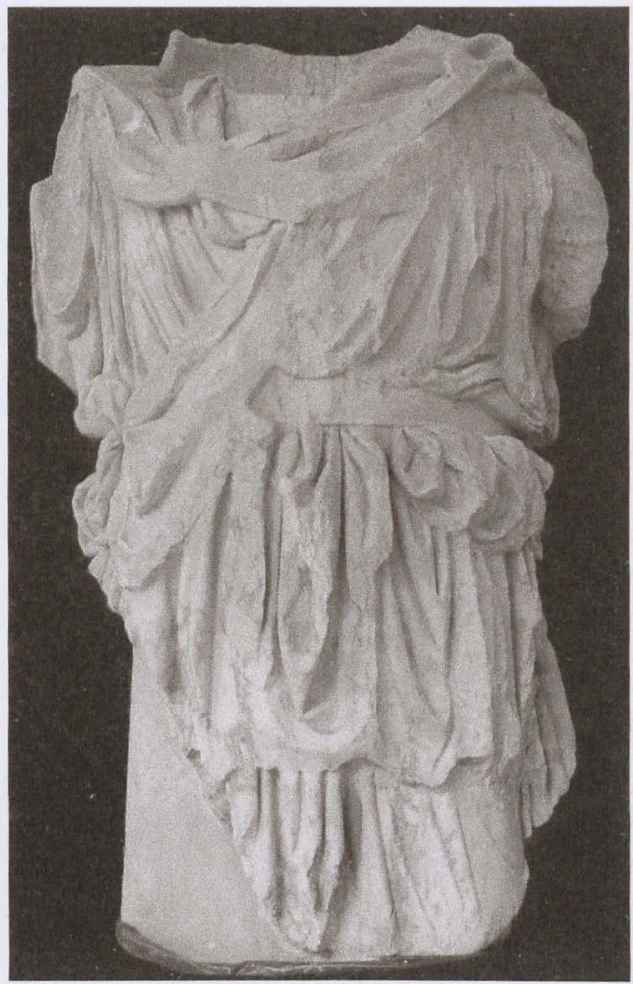

Figure 17.12 Rome, Antiquario Forense. Torso of a handsome Asian statue. After 14 BC. Rome. DAI, Heide Behrens: 2007.6608.

(Fig. I7.I 6 below), Mithras, Orpheus and Paris (Schneider 2007: 76-8). This stereotype allowed different people of Asia Minor and the Near East to be portrayed as uniform and thus essentially the same, whether past or present, mythical or historical. The style of the statues and their heads, both worked to an exceptional finish, links the Asians to the restoration of the Basilica Paulli after I4 BC.

Obvious clues make it possible to reconstruct the original pose of the basilica statues (Fig. I7.I3). The sculptural fragments attest two mirror images characterised by a weighted and a non-weighted leg, either on the left-hand or the right-hand side. The concept of ponderation was complemented by a close correlation of the poses of both arms and legs (Schneider 2007: 72-5). The arm over the weighted leg was raised in an elaborate manner: while the upper arm was stretched horizontally to the side, the lower arm was bent vertically and the hand again horizontally to the side with the palm showing upwards. The position of the arm over the non-weighted leg was a form of antithesis. It pointed diagonally downwards and then back to the body where the hand rested firmly on the hip bone. Hence, the basilica statues were shown in a refined motif of architectural support but without the ability to hold actual weight. ${ }^{22}$ The weighted stance and the 


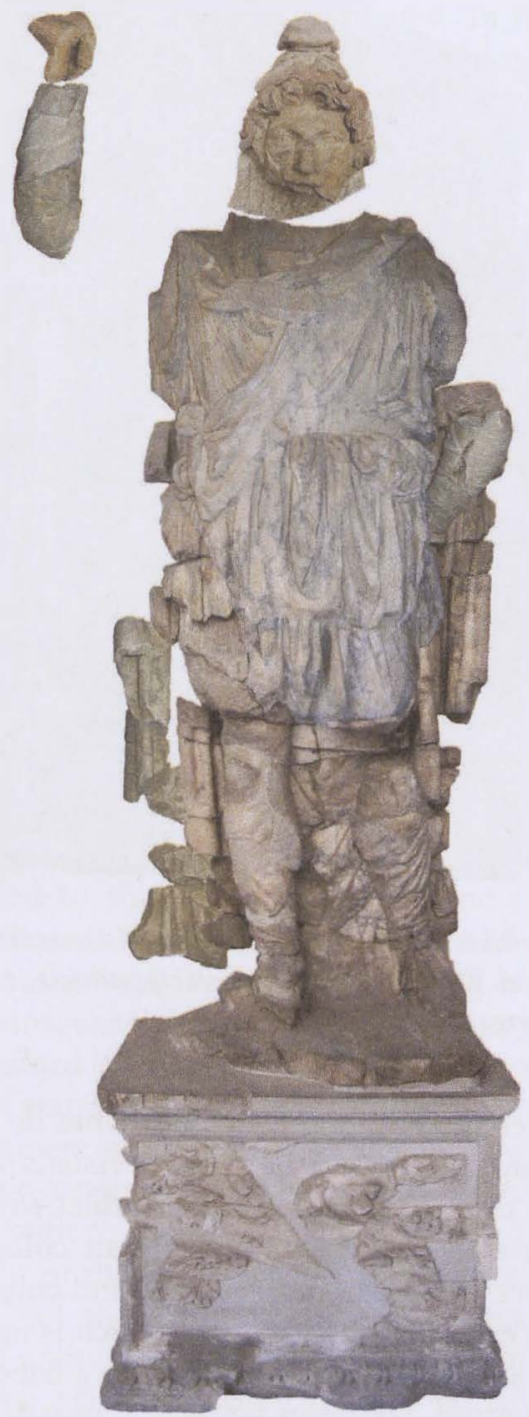

Figure 17.13 Rome, Antiquario Forense. Virtual reconstruction: handsome Asian statue. Antiquario Forense (Tobias Bitterer and Rolf Michael Schneider, 2013). After 14 BC. Ravensburg. Tobias Bitterer.

elaborated pose established a potent Roman image of an exotic Asian: a compliant supporter, very handsome, lavishly dressed, richly coloured and stylishly designed (Fig. I7.I 3). It was a metaphor adopted from Hellenistic art and popular throughout the Roman Empire. ${ }^{23} \mathrm{~A}$ close parallel to the iconography of the basilica statues is the Asian of an architectonic relief, which can be dated to around $\mathrm{AD} 40$ (Fig. I7. I 5 below). ${ }^{24}$ It once adorned (the attic? of) a large grave monument near Avenches measuring originally 


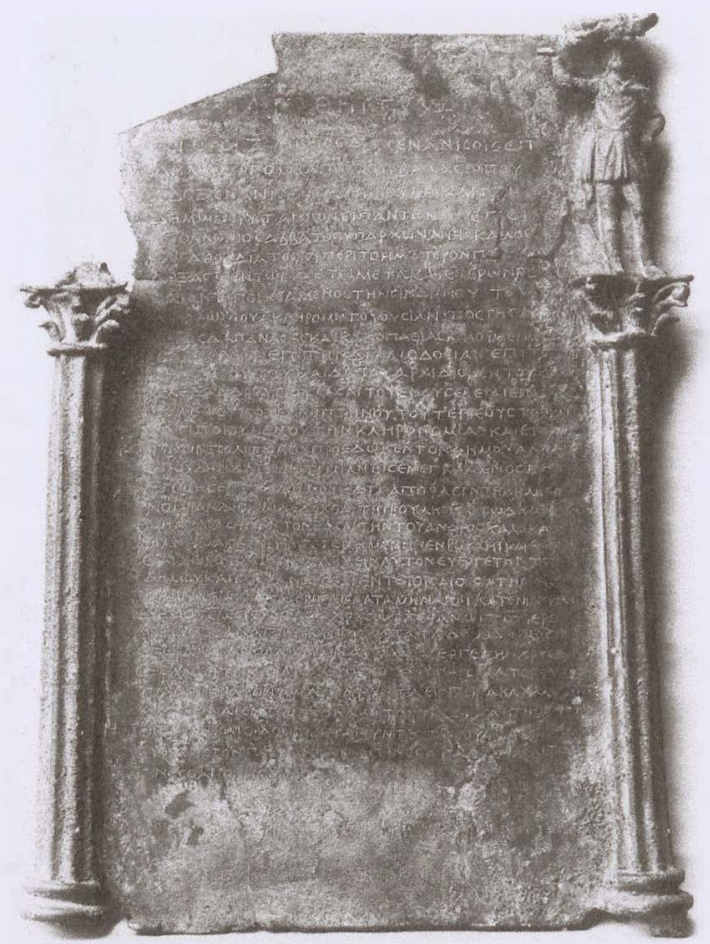

Figure 17.14 Berlin, Antikensammlung, Staatliche Museen. Bronze tablet with inscription (lost in World War II) from Hanisa/Cappadocia. c. 150-100 BC. Berlin. Antikensammlung, Staatliche Museen.

more than $20 \mathrm{~m}$ in height. So far so good, but what do we actually know about the architectonic setting of handsome Asians when they act as figures of support? A case in point is a bronze tablet with a Greek inscription framed on each side by a fluted Corinthian column (Fig. I7.I4). ${ }^{25}$ A handsome Asian, set up on top of the right-hand column, acts as a support figure under the entablature - most of which is missing. This makes the tablet the earliest known example representing a handsome Asian in the pose of the basilica statues. Found in faraway Cappadocia and attributed to the later second century $\mathrm{BC}$, the inscription records that the demos of the otherwise unknown city of Hanisa bestowed a golden wreath upon a certain Apollonios. To sum up, the handsome Asian acting as a support was conceived as an integrai element of architecture and as such was inherently related to the building it adorned. Generally, the handsome Asian was set up above a ground-floor colonnade, be it as a free-standing sculpture or as a figure carved out of a pillar or a half-column. ${ }^{26}$

\section{Reconstructing the basilica}

As it has become evident that the handsome Asian is a vital component of the architectonic blueprint of the Basilica Paulli, I will now tackle the 
building's reconstruction, which has caused an ongoing controversy. Two opposing reconstructions have been presented. In the I970s, Bauer proposed a two-storeyed building with an additional mezzanine in which he placed the handsome Asians based on the decorated pedestals mentioned above, a gallery of, all in all, forty over-life-sized statues (Figs. I7.4-17.7 and $17.12-17.13$ above). ${ }^{27}$ The pedestals (Fig. 17.5a-b above) were set on large matching marble blocks (console geisa) projecting beyond the horizontal geison of the lower colonnade. The statues were related to pilasters and capitals which were, like the pedestals, decorated with tendrils (Lipps 200I: 25-7). According to Bauer (1977; I988; I993b) the portico facing the Forum Romanum was a separate, two-storeyed building crowned with a high attic (Fig. I7.8 above). Freyberger and Ertel (2007) suggested a different reconstruction: a two-storeyed basilica in connection with a separate, one-storey portico crowned with a high attic in which they place the handsome Asians (Figs. 17.9-17.10 above) ${ }^{28}$ Here the portico also serves as a substructure for a large terrace roofed over with a pergola-like construction, supported by the decorated pilasters and capitals which Bauer had placed in his mezzanine (Fig. I7.8 above).

As the Basilica Paulli is a most exceptional building of which crucial architectonic elements are missing, it comes as no surprise that both proposals have shortcomings. One, in particular, is the currently unsolvable problem of how to reconstruct the basilica's upper storey(s). In a smart move, Bauer added to the basilica a mezzanine (Fig. I7.8 above), for which, however, there is no hard proof on site and no structural parallel in Roman architecture. ${ }^{29}$ As there is no matching entablature, he misread the handsome Asians, as we have seen, as Parthians presenting with raised arm a Roman standard (Schneider 20I 2: I I 2-I9). In doing so, he invented an iconography of standing Asians which does not exist and which can be refuted by the fragment of a right hand (Fig. I7.II above). Bauer's further argument for a two-storeyed portico is not substantiated by the evidence (Lipps 20II: I 27 with n. 727).

The weak point of the Freyberger-Ertel reconstruction is their design of the upper part of the portico (Figs. 17.9-17.10 above). Here they locate two sets of architectural decoration: in front of the attic a gallery of fifteen handsome Asians and on top of the portico the decorated pilasters and capitals. The Freyberger-Ertel reconstruction fails for a variety of reasons:

I. Most of the fragments of the Asian statues were found not in front of the portico but inside the basilica (Bitterer 2007: 535-9).

2. The allocatable architectonic elements distinguished by coloured marble or detailed decoration belong to the basilica's naves but not to the portico (Lipps 20I I: I49).

3. None of the portico's geison blocks show traces of the footings of the Asians' pedestals, which they would have done if they had been set up here (Lipps 20I I: I48).

4. Even worse, the geison blocks do not allow enough depth to accommodate the pedestals (Lipps 20I I: I49). 


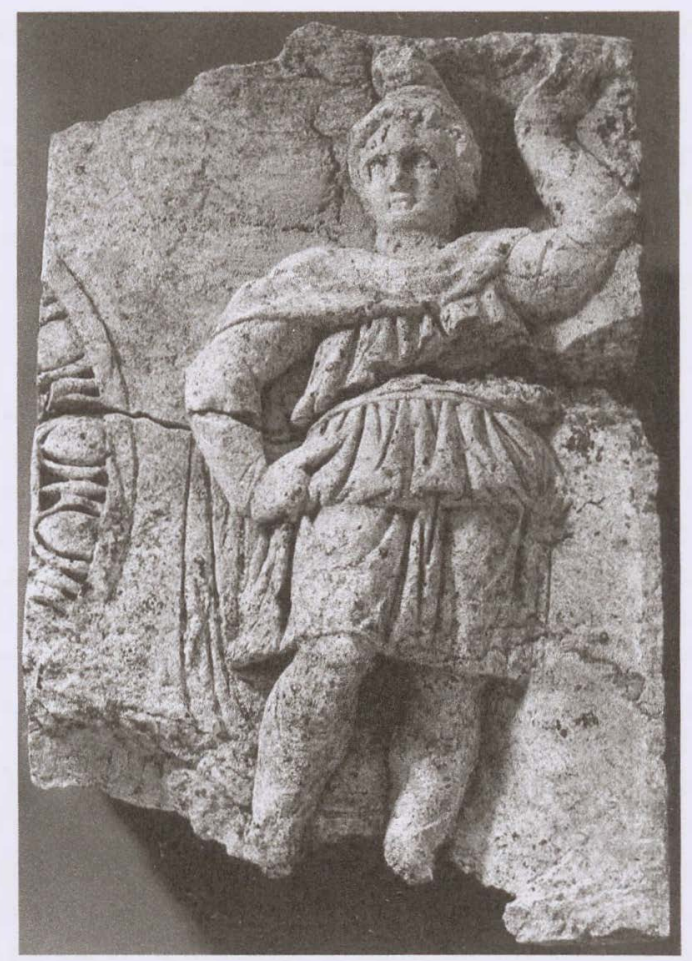

Figure 17.15 Avenches, Musée Romain. Architectural relief from a large local grave monument. c. AD 40. Castella and Flutsch 1990: 25 fig. 9.

5. The hand of a handsome Asian statue is stretched out in an unmistakable pose of support (Fig. I 7. I I above) as part of an established iconographic and architectonic tradition (Fig. I 7.I 4 above and Fig. I 7.I 5 ). ${ }^{30}$

6. As there was no entablature, Freyberger and Ertel also changed the motif of the Asians' raised arm; but unlike Bauer they made it look like the arm of a policeman stopping the traffic (Fig. I7.IO above).

What can we deduce from all this? The Freyberger-Ertel reconstruction requires substantial revision. Bauer's reconstruction of the basilica's lower storey is structurally by and large plausible,,$^{31}$ up to placing the handsome Asians and their pedestals on top of the projecting console geisa, which rested on the lower colonnade of the main nave. The architectonic and iconographic evidence supports the assignment of the statues together with the adorned pedestals, pilasters and capitals to the basilica's upper zone. But how this could be reconstructed constitutes a major puzzle which currently cannot be solved.

\section{Pliny's Phryges}

Around AD 70 Pliny listed the Basilica Paulli among the most magnificent buildings of the world. But as archaeologists and philologists have misread 
Pliny's text, they have failed to recognise why he rated the basilica as one of the world's three most beautiful works. ${ }^{32} \mathrm{~A}$ comprehensible understanding emerges only when one examines the philological and archaeological evidence together. As a first step I will present Pliny's passage in the context of book XXXVI following the established Latin text: ${ }^{33}$

(IOI) But it is time to pass on to the architectonic wonders of our own city and look closely at our ability to learn over the last eight hundred years, and show that here too we have conquered the world. You will see that these victories have occurred almost as often as the wonders have been cited. In fact, if you heaped up all the architectonic wonders and threw them into a single pile, such grandeur would arise as to make you think that no less than another world was being described in one and the same place. ( $\mathrm{IO}_{2}$ ) Even if we do not mention amongst our great achievements the Circus Maximus built by the dictator Caesar - as long as three stadia and as wide as one, with its buildings covering about three acres and seats for two hundred and fifty thousand - should we not include in our magnificent works the basilica of Paul[I]us, which is admired for its columns of Phrygians or the forum of Divus Augustus or the temple of Peace of Vespasianus Imperator Augustus, all of which are the most beautiful buildings the world has ever seen?

All editors of Pliny's text agreed that the Basilica Paulli was admired for its 'columns of Phrygians', read as 'columns made of Phrygian marble'. ${ }^{34}$ This reading, however, is problematic for several reasons. Remains of such columns have never been found. Early attempts to discover them and claims that they were later reused in Rome's San Paolo fuori le mura proved to be wrong (Lanciani I 899). To cut a long story short, the archaeological evidence allows us to draw one conclusion only: such columns never existed. In fact, the basilica columns were, as noted above, made not of marmor Phrygium, but of marmor Luculleum and marmor Carystium. The distinct colouring of the three marbles makes it unlikely that Pliny mixed up the names, especially in his book about (coloured) stones. The reading of columnis e Phrygibus also fails to explain why Pliny praised the former as particularly admirable but excluded the columns in coloured marble which adorned the other two most beautiful works in the world, namely the forum of Augustus and Vespasian's temple of Peace. ${ }^{35}$ The three wonders were set up in the immediate neighbourhood and, hence, competed with each other (Fig. I7.I 8 below). What is more, philological arguments are against the established reading. When identifying the mostly nonRoman origin of marble, Pliny does not refer to it by the noun of the people whose territory supplied the material. He uses an adjective, a location, a quality or the name of an eminent individual, for example marmoris Numidici (V.22), [lapis] Synnadicus (XXXV.3), marmore ... e Paro insula (XXXVI.I 4), [columnae] $e$ Carystio aut Luniensi (XXXVI.48), limina ex Numidico marmore (XXXVI.49), Luculleo marmori (XXXVI.49), columnae porphyrite lapide (XXXVI.88) and Phrygius lapis (XXXVI.I 43)..36 When Pliny employs the noun Phryx, he refers to the Phrygian people, not to the commodities of their homeland. ${ }^{37}$ I conclude that neither the 
archaeological nor the philological evidence backs up the established reading columnis e Phrygibus.

How do Latin manuscripts hand down this passage? To answer this question we need to consult four early Latin codices of Pliny's text. ${ }^{38}$ Two of them, (vetustior) Bambergensis class. 42 of the tenth century (Schneider I986: I 22 fig. I) and (alterius familiae) Vindobonensis CCXXXIV of the twelfth or thirteenth century, transmit columnis e Phrygibus. The other two, both prioris familiae, Florentinus Riccardianus 488 of the eleventh century (Schneider I986: I23 fig. 2) and Parisinus Latinus 6797 of the thirteenth century, hand down columnis et Phrygibus. These four main codices prove no less than that both readings are equally viable. ${ }^{39}$ But why have classicists and archaeologists never considered the alternative reading columnis et Phrygibus a worthy option? As most scholars were unfamiliar with the fragmentary evidence of the Basilica Paulli and its Asian statues in Phrygian marble, the translation 'columns made of Phrygian marble' was a plausible option despite its archaeological and philological shortcomings, as discussed above. But, in fact, it is the published archaeological data of the Basilica Paulli which enable us to disclose and correct the flaws of the established reading. It is the 'lectio difficilior' of columnis et Phrygibus which allows us to relate archaeology, philology and history to each other and to explain why Pliny praised, in particular, the Basilica Paulli with its cutting-edge design and imagery as one of the three most beautiful works the world had ever seen.

But who were the Phrygians Pliny so prominently alludes to? In Roman literature Phryx predominantly signifies the Trojan. Latin authors such as Accius, Ennius, Virgil, Aetna, Horace, Propertius, Ovid, Vitruvius, Festus, Phaedrus, Seneca, Lucan, Petronius, Pliny and numerous others coming after him often employed Phryx when addressing the Trojan..$^{40}$ In doing so they adopted a Greek tradition that was in place perhaps as early as the sixth century BC. $^{41}$ In Rome, this reference was given a new edge by Augustan writers, who related the Trojan Phryges to characteristics such as magnus ${ }^{42}$ semivir,${ }^{43}$, pius, ${ }^{44}$ timidus $^{45}$ and sophus. ${ }^{46}$ Thus the venerated Trojan forefathers of the imperial Gens Iulia and the people of Rome became the subject of multiple readings connecting conflicting ideologies of affinity and difference to each other. However, it does not come as a surprise that the Trojan Phryges were conceived within a wide spectrum of Roman interpretations oscillating between two opposite poles: while the Phrygian forefathers embody Rome's outstanding myth-historical past, ${ }^{47}$ the Phrygian strangers exemplify, with their exceptional setting, luxurious representation and submissive function, particular habits of the Asian.

This literary tradition leaves little doubt that Pliny read the Asian statues so prominently displayed in the Basilica Paulli as images of handsome Trojans, whom he called Phryges in reference to their homeland. There are good reasons for arguing that the basilica's statues had been understood in this way under Augustus. Here portrayals of Aeneas' son, Inlus Ascanius, another handsome Trojan in Asian dress, were omnipresent in Rome. His image distinguished not only works such as the Ara Pacis, the forum of Augustus and the temple of Mars Ultor, but also wall paintings, 
the so-called Tabulae Iliacae, cameos, gems and the like (Schneider 2012). A further Trojan prince showing up in Augustan imagery was Ganymede, Martial's handsome Phryx puer (Epigr. IX.36.2). Crucial here is the overlife-sized statue of Ganymede being seized by Jupiter in the guise of a huge eagle (Fig. I7.I6). This statue was designed as the landmark of the stately villa at Sperlonga (Fig. I7.I7). ${ }^{4^{8}}$ It is the most spectacular image of Ganymede we know of: the only one larger than life, made of Phrygian

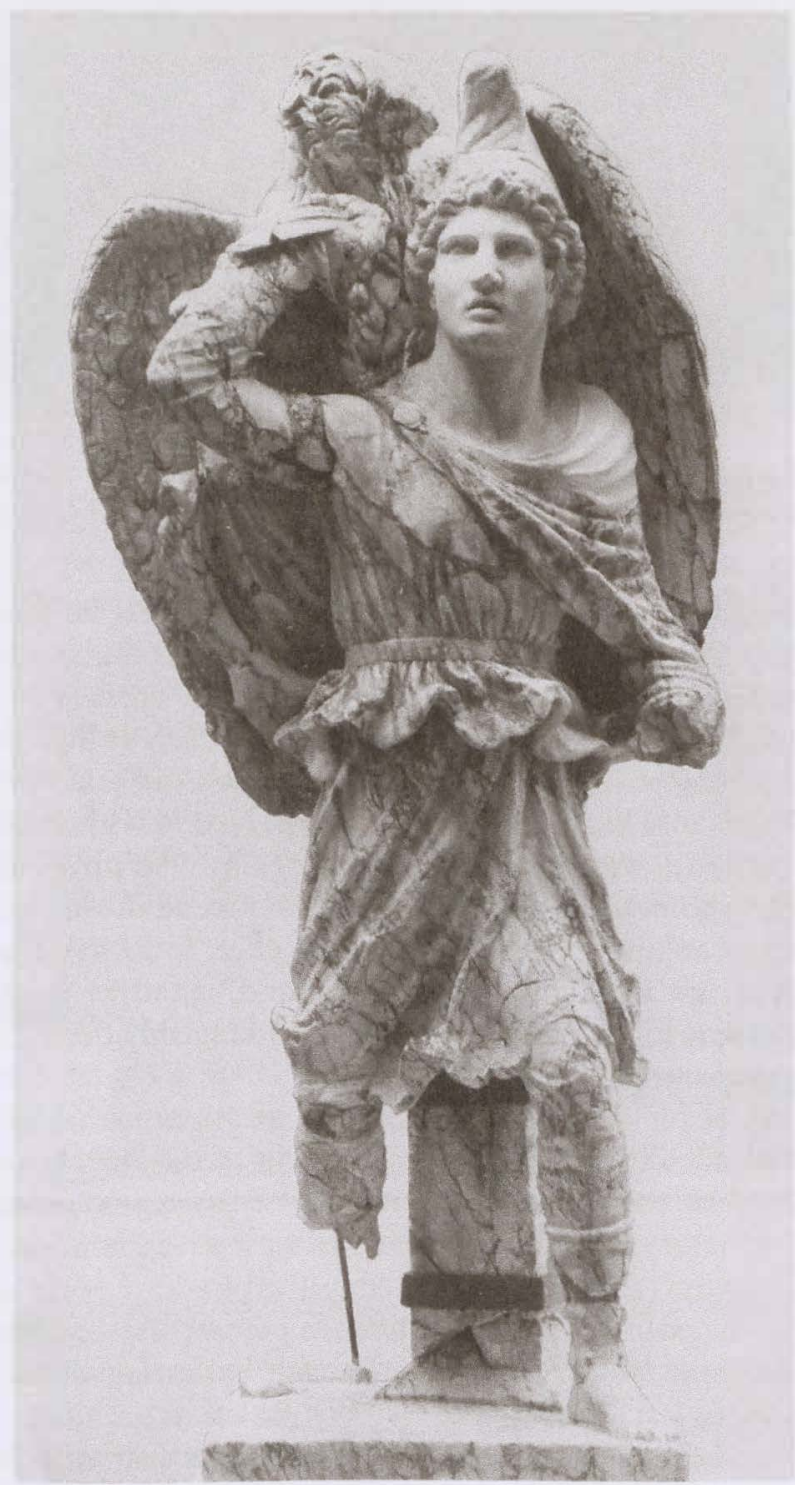

Figure 17.16 Sperlonga, Museo Archeologico. Statue of Ganymede from the stately villa at Sperlonga. Period of Augustus. Munich. Museum für Abgïsse Klassischer Bildwerke. 


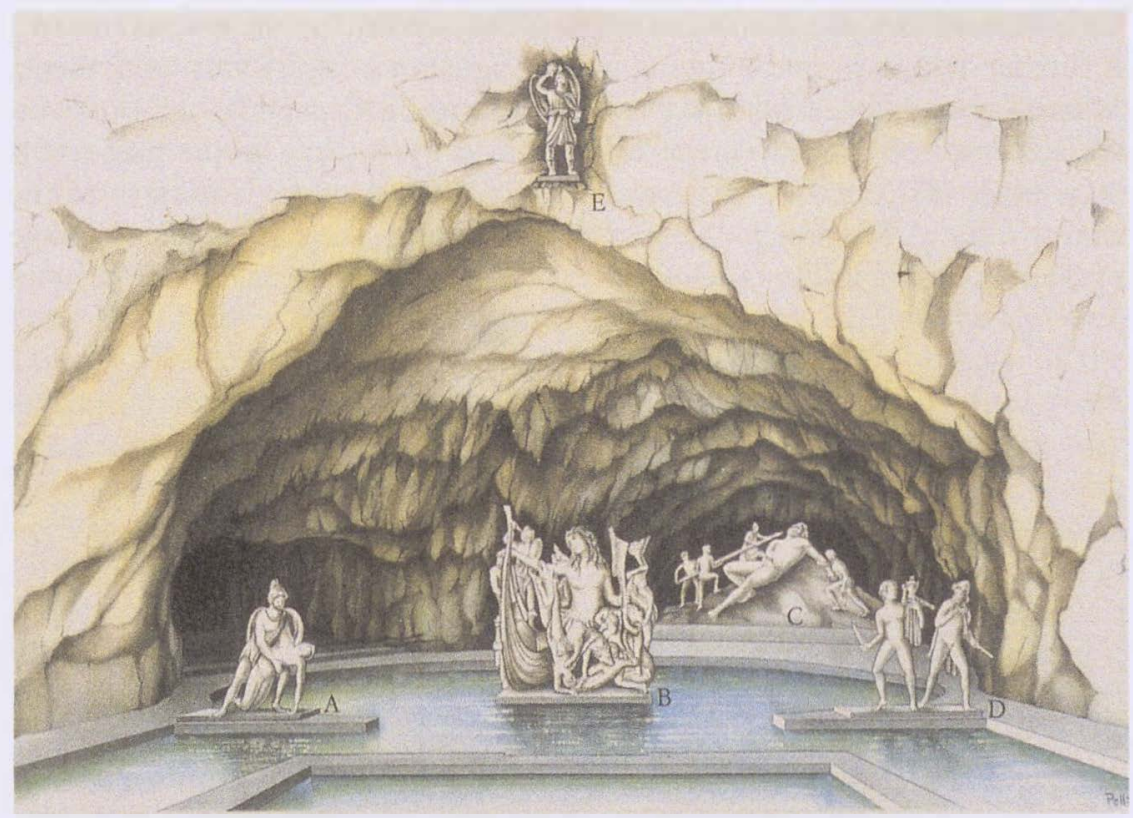

Figure 17.17 Sperlonga, Museo Archeologico. Reconstruction: grotto of the stately villa at Sperlonga. Period of Augustus. Spivey and Squire 2004: 122-3, fig. 205.

marble, dressed in Asian garb and located outside to be seen from far away - on top of a huge grotto in which equally spectacular marble sculptures re-enacted narratives from the epic cycle. The basilica's Trojans and the Ganymede of Sperlonga share many features such as high positioning, size, dress, general pose, handsome face, Phrygian cap and Phrygian marble, while hands and heads were separately carved in white marble. Additionally, both Trojans are portrayed as Phrygians who physically embody their Phrygian homeland. In Sperlonga, Ganymede acted as a mythical waiter to high-ranking members of Rome's elite. In Rome, the gallery of Trojan statues, set up high above the ground, acted as myth-historical images of support in the most avant-garde and lavishly decorated basilica of the early Imperial city.

Less obvious yet not impossible is the assumption that the basilica's statues also alluded to the so-called settlement of the Parthian question in $20 \mathrm{BC}$, claimed by contemporary writers to be Augustus' greatest foreign victory and a major triumph of the Roman west over the Asian east. ${ }^{49}$ The architect Vitruvius (De arch. I.r.6), who lived under Caesar and Augustus, confirms the political topicality of such portrayals. According to him, statues of Persians (statuae Persicae) in rich barbarian dress and posed as (if) supporting architraves were widely set up in architecture for two reasons: to make the eastern enemies tremble for fear of what western bravery could achieve (the latter chimes well with Pliny, who makes this a hallmark of Rome) and to encourage the western viewer to be prepared 
to defend his freedom. There is, however, no textual evidence backing the hypothesis that the basilica's Phryges could have been (also) read as images of Parthians, especially since Augustan poets usually addressed the latter as Medes, Persians or Achaemenians..$^{50}$

\section{Pliny's columns}

A concluding question remains: why did Pliny consider the basilica's columns to be particularly noteworthy and why did he relate them so closely to the Phrygians? As ever, the answer is manifold. The column is a tectonic element and as such associated with the architectural statues of Phrygians in a gesture of support. In addition, the columns and the Phrygians complement each other with their distinct coloured marble, the former in marmor Luculleum and marmor Carystium, the latter in marmor Phrygium. Imperial writers attest an almost idiomatic relationship between columns and pillars in human form. According to Vitruvius (De arch. I.I.5), Caryatides were set up pro columnis in opere. Pliny (Nat. Hist. 36.38) affirms for the Pantheon of M. Agrippa in columnis tem-

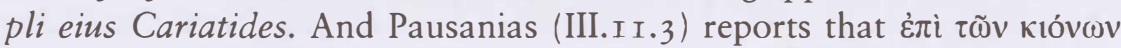

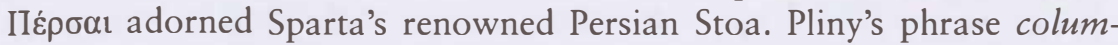
nis et Phrygibus augments this tradition. The prepositions pro, in or غ̇ $\mathrm{i} i$ indicate that the architectural figures of support were positioned above, attached to or in place of columns (Fig. 17.I 4 above). This coincides well with the archaeological evidence of figures of structural support which in Graeco-Roman architecture usually ornamented the upper storey. ${ }^{\text {sI }}$ Statius gave the relationship between a column and a pillar in human form a mythical dimension when he praised Domitian's new palace: 'Here is the august building, immense, not with a mere hundred columns but enough to support the heaven and the gods, were Atlas to ease his burden. ${ }^{92}$ In brief, the column is the identifying marker that signifies the function and setting of architectural figures which act or operate as support.

\section{Context matters}

By now we have got a better idea of why Pliny praised the Basilica Paulli as one of the three most beautiful works the world had ever seen. But what are the miracula in and outside of Rome with which the Basilica Paulli is here competing? ?3 $^{53}$ Before Pliny starts to focus on Rome's constructions he comments at length on the building works of Egypt (Nat. Hist. XXXVI.64-94): obelisks, pyramids, the Sphinx, the Pharos, labyrinths, hanging gardens and the hanging city of Thebes. At the time of Pliny at least five pharaonic obelisks had, for the first time ever, left Egypt and had been transported to Rome, four under Augustus and one under Caligula. ${ }^{54}$ Here they were re-erected in the most popular public spaces and transformed into exotic landmarks of the imperial urbs: as matchless spoils they made supreme Rome's claim to rule the world. It is obvious 
that for Pliny Egypt was a point of reference when it came to Rome. ${ }^{55}$ Compared with the wonders of Egypt the list of Greek wonders is short (Nat. Hist. XXXVI.94-I00). This changes when Pliny tackles the world's top man-made wonders accumulated in Rome. In twenty-four chapters (Nat. Hist. XXXVI.IOI-24) he recites no fewer than eighteen of her numerous miracula:

I. Circus Maximus.

2. Forum Augusti.

3. Templum Pacis.

4. Basilica Paul[1]i.

5. Roof of the Saepta Iulia commissioned by M. Agrippa.

6. Roof of a theatre at Rome constructed by the architect Valerius of Ostia.

7. Forum Iulium with reference to the Pharaonic pyramids.

8. Domus of Clodius.

9. Foundations of the Capitol.

ro. Public sewers, especially the Cloaca Maxima, transforming Rome like Egyptian Thebes into a hanging city (urbem pensilem).

I I. Domus of Lepidus.

I 2. Residence of Caligula.

I3. Residence of Nero.

I4. Temporary theatre of M. Aemilius Scaurus.

I 5. Two temporary theatres of $\mathrm{C}$. Curio able to swing around to form an amphitheatre.

I6. Aqueduct of Q. Marcius Rex.

I7. Works of M. Agrippa including aqueducts, 700 wells and 500 fountains (ornamented with 300 bronze or marble statues ${ }^{56}$ and 400 marble columns), and 170 baths.

I8. Finally, aqueducts of Caligula and Claudius.

Outside Rome, Pliny (Nat. Hist. XXXVI.I25) lists the harbour of Ostia and the miracula of Italy such as roads, the separation of the Tyrrhenian Sea from Lake Lucrinus by an embankment, vast numbers of bridges and the marble quarries.

Rome's architectonic wonders differ distinctly from the ones Pliny recited before. In striking contrast to Egypt, all the works he listed for Rome address aspects of public and domestic life despite Pliny's scorching criticism of (private) sumptuousness: spaces for political and religious rituals such as the imperial fora; buildings for social and financial activities such as the Basilica Paulli; spaces for mass entertainment and communication such as the Circus Maximus, theatres and baths; complex examples of public infrastructure such as sewers, aqueducts, wells, fountains, roads and bridges; and places for living in, in which, ideally, public and domestic affairs were settled, such as the residences of the emperors and the very rich. In this list of marvellous works the Basilica Paulli stands out as the sole building supplying, besides an exceptional space for the public, a unique gallery of handsome Trojans serving to excite stories about Rome's myth-historical past and her right to claim reign over the world. 
For a more nuanced understanding of the basilica, the Trojans and the list of Rome's wonders we need to go back to Pliny's initial chapter, Ior. Here he gloats over the fact that Rome has conquered the world with her inimitable works. He relates this claim to the city's outstanding ability to learn over the previous 800 years or, in other words, to appropriate and perfect skills such as strategy, knowledge and technique. ${ }^{57}$ In a further step he links the frequency of Rome's victories to the rate of public response to her buildings, which formed, as we have seen above, the city's public infrastructure. In making this point, Pliny refers to a long-standing practice set up by Roman generals. After gaining a victory, they financed major public constructions in the city de or ex manubiis. ${ }^{58}$ This enabled them to turn part of their (vast) military booty into symbolic capital and, thus, enhance their constantly competitive campaigns for more political power in Rome. Then Pliny takes stock, in saying that Rome alone has accomplished so many architectonic wonders that, in doing so, she crafted another mun$d u s$ in addition to the orbis terrarium she had already conquered. Finally, Pliny's opening reference to Rome's very beginnings, 800 years before, is connected to the city's claim to her myth-historical descent from Troy. It was Troy's downfall which led to the arrival of Trojans in Latium and the foundation of Rome. It is hardly a coincidence that this claim is at the core of two of the three wonders shortlisted by Pliny: the Basilica Paulli and the forum of Augustus. Yet only the basilica was adorned with a gallery of handsome Trojans meant to endorse forever Rome's claim of universal uniqueness. The reading of the Trojan statues was complemented by the long marble frieze which decorated the nave(s) of the Augustan basilica. The frieze depicts stories of the city's myth-historical past, namely selected narratives of Aeneas and Romulus, her Trojan forefathers. ${ }^{59}$

The array of coloured marble inside the basilica would have fuelled further debates. ${ }^{60}$ The over-life-sized statues of the basilica's Trojans were the first of their kind to be sculpted in coloured marble. For them only the most expensive stones had been chosen, mostly marmor Phrygium, but occasionally marmor Numidicum, which would have permitted allusions to Dido and Aeneas. As the quarries of the two marbles were situated in distant provinces and required a global infrastructure to be transported to Rome, the new polychromes constituted a distinct symbol of the city's global power or, in other words, a new material map of her Empire. ${ }^{6 r}$ The exotic colour and high polish of the basilica's Trojans enhanced their presence, intensity and meaning as they personified commodities never before seen in Rome. The preferred use of Phrygian marble to portray the basilica's Phryges opened up further readings. From Augustus onwards this marble became known as Phrygium (Schneider 1986: I 40-I), signifying the homeland of Troy and, in a wider sense, also that of Rome as her powerful successor. Phrygian marble was not only the most suitable substance for the basilica's Trojans; it also allowed multiple allusions to their famous homeland. ${ }^{62}$ As most of the polychromes became Imperial property under Augustus, a new ideology of place, colour, history and power took shape. ${ }^{63}$ The earliest known icons of this ideology were the basilica's Trojans (Figs. I7.4-I7.7 and I7.I2-I7.I3 above), the Trojan prince Ganymede in Sperlonga (Fig. I7.I 6 above) and 
three over-life-sized statues of handsome kneeling Asians (who carried a bronze tripod) in Rome and Athens, all made of Phrygian marble and set up under Augustus. ${ }^{64}$

Of Trojan origin was not only the Phrygian marble but also the Phrygian cap, an essential of the Near Eastern dress in Graeco-Roman art (Fig. I7.6 above). ${ }^{65}$ Juvenal is the first to call the headgear by this name. ${ }^{66}$ He describes the Phrygia bucca tiara as part of the dress of the semivir Gallus, the self-castrated and flamboyantly foreign attendant(s) of Mater Magna, who was, since the period of Augustus, also known as Mater Deum Magna Idea, the great Trojan foremother of all gods. ${ }^{67}$ Her temple was built on top of the Palatine Hill, next to the temple of Victory. This was a prominent location, with Mater Magna becoming integrated into one of the city's most symbolic landscapes, the core area of her mythhistorical past. A military version of the Phrygian cap was the Phrygian helmet. On coins struck in Republican Rome the goddess Roma is sometimes depicted with a Phrygian helmet, another strong marker of Rome's Trojan descent. ${ }^{68}$ Later in history, the Phrygian cap served new masters in the west. The most famous was the bonnet rouge of the Jacobins in the French Revolution (Wrigley I997).

\section{Intentional history}

The Phryges of the Basilica Paulli - wrongly thought to signify the Phrygian marble of columns which did not exist - attest a new visual presence and concept of Trojans in Augustan Rome. They are handsome, exotic, luxurious and portrayed in a stylish pose ready to support, in stone, diverse claims of the new regime: Rome's distinguished myth-historical past; her (seemingly) unlimited control over foreign peoples, resources and homelands; her ability to integrate on a large scale the foreign as an essential of what had made Rome universally distinct; and her ability to transform political claims into pervasive icons of multiple reading. Although we are not yet able to confirm the basilica's Trojans' precise setting, they constituted a spectacular case in point, as a gallery of formerly perhaps forty over-life-sized statues in Trojan marble placed not, as tradition has it, outside on the façade but inside the basilica's abundantly adorned hall. This setting was an exceptional move, as it marked a pointed contrast to the setting of another spectacular gallery of figures of architectural support: the Caryatides in the forum of Augustus. ${ }^{69}$ We should keep in mind that the forum was constructed in the immediate vicinity of and at about the same time as the basilica, and that both occupied and perhaps even shared an immense building site (Fig. I7.I8). Following the Greek tradition, the Caryatides were displayed outside, in the attic of the two porticoes framing the forum's longer sides. In closest proximity the Basilica Paulli and the Forum Augustum offered two different spaces, two different designs and two different galleries of architectural figures acting or operating as support. In their structural and symbolic function they seem to represent some of Rome's earliest known over-life-sized architectural statues. In this role 


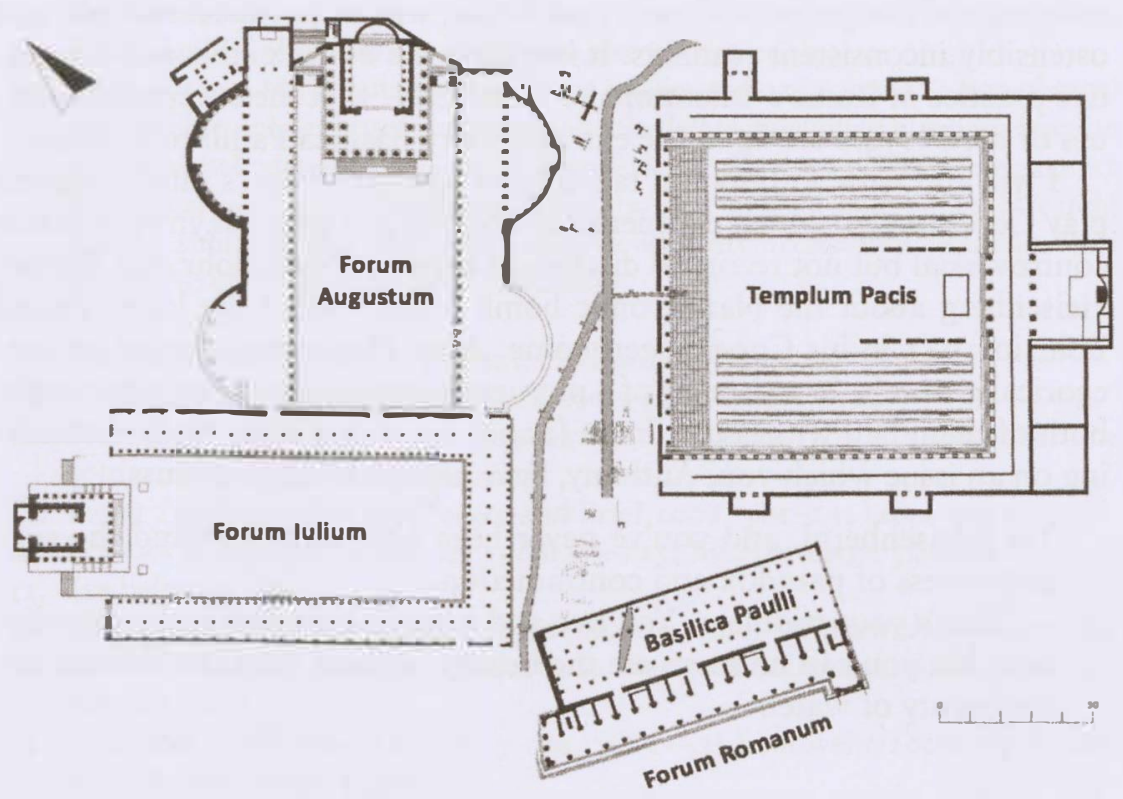

Figure 17.18 Rome, Imperial fora near the Basilica Paulli. Period of Vespasian. Carnabuci and Bruccalenti 2011: 39, fig. 8 (modified).

they were sure to attract attention and stimulate debate, and contribute to the complex ideologies of Rome's new emperor. What is more, both seem to echo the famous Caryatides and Persian statues cited by Vitruvius ( $D e$ arch. I.I.5-6) as the only two examples of architectural ornamenta whose history every architect ought to know. ${ }^{70}$ Is all this just a mere coincidence? The basilica's Trojans also facilitated another comparison with Augustus' forum. The Trojan forefathers in the forum - Aeneas, Anchises and Iulus Ascanius - were individualised and distinguished by dress, age and habit, ${ }^{7 r}$ whereas in the basilica they were an anonymous collective characterised by handsome sameness and support.

The basilica's Phryges constitute in terms of hermeneutics too a case in point. They show how easily a misunderstanding in scholarship can achieve the status of communis opinio and, in doing so, prevent further research. They mark exemplarily that neighbouring disciplines, despite claims to the contrary, like separate tables (Snodgrass 2006). Another obstacle is that statues of Phryges do not fit the clear-cut semantic categories still dominant in philology, archaeology and ancient (art) history. To the present day, images which elude such definite taxonomies are not much liked. They can be understood only when we accept transgressing readings like 'as well as' and do not insist on a categorical 'either/or'. The conflicting interpretations I have suggested for the Phryges of the Basilica Paulli are usually even less liked, in particular when they contradict the framework of an intentional and coherent understanding. But this, I argue, neglects a vital agency of intentionality which, especially in the richly conceptualised 
realities and imageries of Greece and Rome, was to produce multiple and ostensibly inconsistent readings. It is within the both flexible and normative practice of Rome's 'intentionaler Geschichte' that the exceptional statues of the Phryges set up in the extraordinary Basilica Paulli took shape.

I will end with a quotation taken from Michael Frayn's much-debated play Copenhagen, which premiered in London in 1998. Frayn re-enacts a controversial but not recorded discussion between Niels Bohr and Werner Heisenberg about the Nazi atomic bomb project when the latter visited Bohr in I94 I in his Copenhagen home. After Heisenberg denied on categorical grounds the existence of a physical anomaly during an experiment both of them had witnessed, Frayn (2000: 65-6) has Bohr reply - touching on an issue which you, Anthony, have always liked to discuss:

Yes [Heisenberg], and you've never been able to understand the suggestiveness of paradox and contradiction.

That's your problem. You live and breathe paradox and contradiction, but you can no more see the beauty of them than the fish can see the beauty of water.

\section{Acknowledgements}

For help and criticism I thank Anna Anguissola, Tobias Bitterer, Annarita Doronzio, Johannes Lipps, Susanne Muth, Bianca Schröder, and especially Angela. For supplying photographs I am indebted to Heide Behrens, Rome; Tobias Bitterer, Ravensburg; Johannes Lipps, Tübingen; Museum für Abgüsse Klassischer Bildwerke, Munich; Antikensammlung, Staatliche Museen, Berlin. K. S. Freyberger and K. Tacke, Die Basilica Aemilia auf dem Forum Romanum in Rom. Wiesbaden: Dr Ludwig Reichert, 2016, not yet published.

\section{Notes}

I. www.digitales-forum-romanum.de/gebaeude/basilica-paulli/?lang=en (with further bibliography; last visited 8 July 2016).

2. Ancient texts: Platner and Ashby 1929: 72-6; Bauer I993a; Steinby I993; Chioffi I996: 37-43.

3. Steinby I993; the archaeological remains which she tentatively attributes to the 'Basilica Aemilia' are too scant to sustain her argument.

4. Freyberger and Ertel 2007: 493 n. 2; Lipps 20II: 23-7.

5. Lanciani I899; I900: 3-8; Hülsen I902: 4I-57; I905: 53-62; Vaglieri I903: 83-99; Boni r904.

6. Bartoli I912; Van Deman 1913.

7. Carettoni 1948; 1960: 192-3.

8. Andreae I957: I49-77.

9. Bauer I977; I988; I993a; I993b; Lipps 20II: 24-7 fig. I.

I0. Much of the following information is based on oral communication with Laura Fabbrini and Heinrich Bauer in Rome (1980); see also Boni 1904: 569; Bartoli I9I2: 760; Van Deman I9I3: I7 fig. 2; Fabbrini I972: 64; Schneider I986: I I 5; Bitterer 2007: 535-9. For the basilica's marble frieze see below, n. 59.

I I. Schneider I986: I I 5 n. 786 pl. $25 ; 2002: 86$ fig. 2. 
I2. See above, n. 9.

I3. Schneider I986: 98-I02, I I 5-25; see also above, n. Io.

I4. Lipps 20 I I. A full documentation of the architectonic remains (c. 5,000 photos) is accessible online: http://arachne.uni-koeln.de/arachne/index.php?view[section ]=uebersicht\&view[layout]=objekt_item\&view[caller][project]=\&view[page]=I \&view[category]=overview\&search[data]=ALL\&search[mode]=meta\&search[ match]=similar\&view[active_tab]=overview\&search[constraints]=basilica $\% 20$ aemilia\% 2 olipps (last visited 8 July 20I6).

I 5. See above, n. I.

I6. For the date and political context, Hollstein I993: 224.

I7. Freyberger and Ertel 2007; Bitterer 2007; Lipps 20II; 2014.

I8. Freyberger and Ertel 2007: 509-II fig. I9; Lipps 20II: 36-82. For the coloured marbles, Pensabene 2013.

I9. Bauer I993b: I85-6; Freyberger and Ertel 2007: 50I-23; Lipps 201 I.

20. For this paragraph, Schneider I986: 98-I25; Bitterer 2007: 535-46.

2I. See below, n. 48 .

22. (Fantastic) figures composed to hold (architectonic) weight without being able to do so in reality became popular in Roman wall painting around $40-20 \mathrm{BC}$; Strocka 2007.

23. Schneider I986: 98-I38, 200-7 nos. SO I-52; Landwehr 2000: 74-83 no. I IO; Bitterer 2007: 546-9.

24. Castella and Flutsch I990: 25 fig. 9; Bitterer 2007: 548-9; Schneider 2007: 75 with n. I09.

25. Robert I963: 498-9; Schneider I986: I00, 206-7 (SO 44); Berges and Nollé 2000: 336-7, 37I, 483-4, 502; Bitterer 2007: 546-7 fig. 63 .

26. Schneider I986: 202 ( $\mathrm{SO} 24$ ), 204 ( $\mathrm{SO}_{27}$ ), 206-7 (SO 44), 207 (47-52), 209 (SO 63-4), 2 Io (SO 65-8); Landwehr 2000: 74-83 no. I Io.

27. Bauer I977; I988; I993a; I993b; Lipps 20II: 26-7 figs. 3-4.

28. Freyberger and Ertel 2007: 5 I 5 fig. 2I; Lipps 20II: I47-9 figs. I33-4; 20I4: I 56-7 fig. 2.

29. Lipps 20II: 82 , I27, I47, emphasising the shortcomings of Bauer's reconstruction.

30. See above, n. 23 .

3I. Lipps 20II: 80, I43-9, marking the main points in need of revision; 20I4: I 56-7 figs. 2-3.

32. First shown by Schneider I986: I 20-5; see also Fant I999: 278.

33. (IOI) Verum et ad urbis nostrae miracula transire conveniat DCCCque annorum dociles scrutari vires et sic quoque terrarum orbem victum ostendere. quod accidisse totiens paene, quot referentur miracula, apparebit; universitate vero acervata et in quendam unum cumulum coiecta non alia magnitudo exurget quam si mundus alius quidam in uno loco narretur. (IO2) nec ut circum maximum a Caesare dictatore exstructum longitudine stadiorum trium, latitudine unius, sed cum aedificiis iugerum quaternum, ad sedem $\overline{\mathrm{CCL}}$, inter magna opera dicamus: non inter magnifica basilicam Pauli columnis e[t] Phrygibus mirabilem forumque divi Augusti et templum Pacis Vespasiani Imp. Aug., pulcherrima operum, quae umquam vidit orbis?

34. Bostock and Riley I857; Mayhoff I 897; André et al. I98I; Corso et al. I988; König and Hopp I992; Möller and Vogel 2007.

35. Forum Augustum: see below, n. 69. Templum Pacis: see Ungaro 2007: 170-7; Meneghini et al. 2009; Fraioli 20I2; Meneghini and Rea 20I4: 242-34I.

36. For Phrygia and Phryx in Pliny, see Schneider I967: I73-4.

37. Pliny, Nat. Hist. V.I45, VII.I97, 202, 204, I99, VIII.I96, XXX.I 3 I. 
38. Mayhoff I 897: ‘Conspectus Codicum' IV-IX; Kroll I95 I: 43 I-4; André et al. I98 I: 36,45 .

39. Contra Corso et al. I998: 659 n. 2, who state that the modern ranking of the four codices provides a decisive argument against columnis et Phrygibus. This transcript, I argue, was the 'lectio difficilior' of the lost archetype and kept by Florentinus Riccardianus 488 and Parisinus Latinus 6797, while Bambergensis class. 42 , for a better understanding one might argue, corrected the 'lectio difficilior' and either eliminated an irritating ' $t$ ' or (mis)read ' $t$ ' as ' $x$ '.

40. Accius, Nyctegresia VII.489, ed. D’Anto, I44; Ennius, 332 (Bruges), ed. Ribbeck, 64; Virgil, Aeneid I.468, II.I9I, 344, V.785, VII.294, IX.I 34, 599, 6I4-20, 635, X.255, XI.I45, I70, XII.99; Aetna, 59I; Horace, Od. I.I 5.34; Propertius, IV.r.2; Ovid, Epist. I86; Ovid, Met. XII.70, 6I 2, XIII.389, 435, XV.452; Ovid, Fasti IV.223, 272, 274, 943, VI.473; Ovid, Ibis 628; Vitruvius, II.I.5; Festus, 364, 5 I0, ed. Lindsay; Phaedrus, app. XIII.2, ed. Guaglianone, Io0; Seneca, Agamem. 206, 550, 705, 743, 758, 869-70, 876, I005; Seneca, Troiad. 29, I 25, 277, 434, 462, 469, 474, 532, 57I, 758, 864, 888, 955, I I 35, I I 57; Lucan, IX.976, 999; Petronius, Sat. LXXXIX. 2; Pliny, Nat. Hist. VII.202, 8.I96. The full evidence is accessible in Munich's splendid Thesaurus Linguae Latinae.

4I. Hall I988; Wilhelm I988.

42. Virgil, Aeneid XI.I45, I70.

43. Ibid. XII.99; Martial, Epigr. IX.20.8.

44. Ovid, Fasti IV. 274.

45. Ovid, Ibis 628.

46. Phaedrus, app. XIII.2, ed. Guaglianone, Ioo.

47. For 'Mythistorie' within the concept of 'intentionaler Geschichte', see Gehrke 2014 .

48. Spivey and Squire 2004: I 22-3 fig. 205; Schneider 20I 2: 88-96.

49. Here and for the following, Schneider I986: 98-I38; 20I 2: I I 2-I9.

50. Schneider 2007: 70 with n. 9I.

5 I. See above, n. 23.

52. Silvae IV.2.18-20: tectum augustum, ingens, non centum insigne columnis, sed quantae superos caelumque Atlante remisso sustenare queant.

53. For Pliny's miracula in book XXXVI, see Isager I986; I99 I: I86-203; Carey 2003: 86-9; Favro 2006.

54. Nat. Hist. XXXVI.70-4; Schneider 2004; Biermann 20I3; Wirsching 2013.

55. For further comments on Egypt and Rome, Isager I99I: I90-9; SwetnamBurland 2015.

56. Not acknowledged by Corso et al. I998: 659 n. 2, who claim 'Plinio sta qui parlando dell'impiego del marmo (sic) in elementi e impianti architettonici trai quali non inserisce alcuna raffigurazione scolpita o dipinta.'

57. For forms of Augustan transformation of Roman knowledge, Wallace-Hadrill 2007.

58. Shatzman I972; Koch 2009; Tarpin 2009; Kay 2014: 87-106.

59. Schneider I986: I I8; Kränzle I994; Freyberger and Ertel 2007: 502-8; Lipps 2OII: $52-3$, reviewing the controversy about the frieze's location.

60. Schneider I986: I39-60; 200I; 2002; Pensabene 2013.

6I. A map of Roman marble quarries is provided in Wittke et al. 2007: 84.

62. For example, Statius, Silv. I.5.36-7, who recounts that the Phrygian Attis had coloured the Phrygian marble by staining it with shiny drops of his own blood. 
63. Schneider I986: I39-60; Maischberger I997: I8-I9; Bradley 2009.

64. Schneider I986: I 8-97, I 88-95 nos. KO I-3; 2002: 84-8; Fejfer 2002.

65. Hinz I974: 790-2; Seiterle I985; Schneider 1986: I 23-4; Rose 2005: 34-5.

66. Juvenal, Sat. VI.5I3-I6: semivir (sc. Gallus) ... plebeia et Phrygia vestitur bucca tiara.

67. Here and for the following, Schneider 20I 2: I 22.

68. Crawford I974: nos. I9.2, 2I.I, 22.I, 24.I, 26.4, 27.5, 4 I.I, 98A.3, IO2.2b-C, 269. I, 288.I, 464.3 b; Rose 2002: 33 I-2 fig. 3.

69. Zanker I968; Kockel I995; Spannagel I999; La Rocca 200I; Haselberger and Humphrey 2006: I 27-30, I83-90; Ungaro 2007: I I8-69; Geiger 2008; Meneghini 2009: 59-78; Carnabuci and Braccalenti 20II; Boschung 2014.

70. Schneider I986: I03-8; King I998: 275-89; Lesk 2007.

7I. Spannagel I999: 90-I3I, 365-96 nos. A I-A I4I; Smith 2013: 204-6 no. $\mathrm{D}_{4}, 292-3$.

\section{Bibliography}

André, J., R. Bloch and A. Rouveret (eds) (I98I), Pline l'Ancien: Histoire Naturelle Livre 36, Paris: Les Belles Lettres.

Andreae, B. (1957), 'Archäologische Funde und Grabungen im Bereich der Soprintendenzen von Rom I949-1956/57', AA 22, pp. I10-358.

Bartoli, A. (I9I2), 'Ultime vicende e trasformazioni cristiane della Basilica Emilia', Rendiconti dell'Accademia nazionale dei Lincei, Classe di scienze morali, storiche e flologiche $2 \mathrm{I}$, pp. 758-66.

Bauer, H. (I977), 'Basilica Aemilia', Mitteilungen des Deutschen ArchäologenVerbandes 8(2), pp. 87-93.

Bauer, H. (I988), 'Basilica Aemilia', in Augustus und die verlorene Republik: Eine Ausstellung im Martin-Gropius-Bau Berlin, 7. Juni-14. August 1988, Berlin: Antikensammlung, Staatliche Museen Preußischer Kulturbesitz, pp. 200-I 2.

Bauer, H. (I993a), 'Basilica Fulvia', in E. M. Steinby (ed.), Lexicon Topographicum Urbis Romae. I: A-C, Rome: Quasar, pp. I73-5.

Bauer, H. (I993b), 'Basilica Paul(1)i', in E. M. Steinby (ed.), Lexicon Topographicum Urbis Romae. I: A-C, Rome: Quasar, pp. I 83-7.

Berges, D. and J. Nollé (2000), Tyana: Archäologisch-historische Untersuchungen zum südwestlichen Kappadokien, Bonn: Dr. Rudolf Habelt.

Biermann, V. (2013), 'Ortswechsel: Überlegungen zur Bedeutung der Bewegung schwerer Lasten für die Wirkung und Rezeption monumentaler Architektur am Beispiel des Vatikanischen Obelisken', in S. Altekamp, C. Marcks-Jacobs and P. Seiler (eds), Perspektiven der Spolienforschung I: Spoliierung und Transposition, Berlin: De Gruyter, pp. I23-56.

Bitterer, T. (2007), 'Neue Forschungen zur Basilica Aemilia auf dem Forum Romanum: Die Orientalenstatuen', $M D A I(R)$ I I3, pp. 535-52.

Boni, G. (I904), 'Foro Romano', in Atti del congresso internazionale di scienze storiche, Rome, I-9 April I903, vol. 5, Rome: Tipografia della R. Accademia dei Lincei, pp. 493-584.

Boschung, D. (2014), 'Kontextwechsel und Neuinterpretation: Das Beispiel der Skulpturen vom Augustusforum', in D. Boschung and L. Jäger (eds), Formkonstanz und Bedeutungswandel, Paderborn: Fink, pp. I27-6I.

Bostock, J. and H. T. Riley (eds) (I 857), The Natural History of Pliny, vol. 6, London: Bohn. 
Bradley, M. (2009), Colour and Meaning in Ancient Rome, Cambridge: Cambridge University Press.

Carettoni, G. (I948), 'Esplorazione nella basilica Emilia', Notizie degli scavi di antichità I I, pp. I I I-28.

Carettoni, G. (I960), 'Excavations and discoveries in the Forum Romanum and on the Palatine during the last fifty years', Journal of Roman Studies 50, pp. I92-203.

Carey, S. (2003), Pliny's Catalogue of Culture, Art and Empire in the 'Natural History', Oxford: Oxford University Press.

Carnabuci, E. and L. Braccalenti (20I I), 'Nuove ipotesi per una rilettura del settore meridionale del Foro di Augusto', Bull. Com. Arch. I I 2, pp. 35-65.

Castella, D. and L. Flutsch (I990), 'Sanctuaires et monuments funéraires à Avenches: En Chaplix VD', Archäologie der Schweiz I3, pp. 2-30.

Chioff, L. (I996), Gli elogia augustei del foro romano: Aspetti epigrafici e topografici, Rome: Quasar.

Corso, A., R. Mugellesi and G. Rosati (eds) (I988), Plinio: Storia Naturale. Mineralogia e storia dell'arte: Libri 33-37, Traduzioni e note 5, Turin: Einaudi.

Crawford, M. (I974), Roman Republican Coinage, 2 vols, Cambridge: Cambridge University Press.

Deman, E. B. van (I9I3), 'Porticus of Gaius and Lucius', AJA I7, pp. I4-28.

Eichholz, D. E. (ed.) (1962), Pliny: Natural History, with an English Translation Io, Loeb Classical Library 4I9, London and Cambridge, MA: Harvard University Press.

Fabbrini, L. (1972), 'Basilica Emilia', Bull. Com. Arch. 83, p. 64.

Fant, C. J. (I999), 'Augustus and the city of marble', in M. Schvoerer (ed.), Archéomatéiaux: Marbres et Autres Roches. Actes de la IVème Conférence Internationale de l'Association pour l'Étude des Marbres et Autres Roches Utilisés dans le Passé, Bordeaux: Centre de Recherche en Physique Appliquée à l'Archéologie and Presses Universitaires de Bordeaux, pp. 277-80.

Favro, D. (2006), 'The iconicity of ancient Rome', Urban History 33, pp. 20-38.

Fejfer, J. (2002), 'Barbaro inginocchiato', in M. De Nuccio and L. Ungaro (eds), I marmi colorati della Roma imperiale: Rome, Mercati di Traiano, exhibition 28th September 2002-I9th January 2003, Venice: Marsilio, pp. 433-6, nos. I 36-8.

Fraioli, F. (20I2), 'La città e le sue parti: Regione IV, T'emplum Pacis', in A. Carandini and P. Carafa (eds), Atlante di Roma antica: Biografia e ritratti della città. I: Testi e immagini, Milan: Electa, pp. 28I-306.

Frayn, M. (2000), Copenhagen, rev. edn, London: Methuen.

Freyberger K. S. and C. Ertel (2007), 'Neue Forschungen zur Basilica Aemilia auf dem Forum Romanum, Zur Baugeschichte, Rekonstruktion und Funktion', $M D A I(R)$ I I 3, pp. 493-524.

Gehrke, H.-J. (20I4), Geschichte als Element antiker Kultur: Die Griechen und ihre Geschichte(n), Berlin and Boston: De Gruyter.

Geiger, J. (2008), The First Hall of Fame: A Study of the Statues in the Forum Augustum, Mnemosyne Suppl. 295, Leiden: E. J. Brill.

Hall, E. (I988), 'When did the Trojans turn into Phrygians? Alcaeus 42.I 5', ZPE 73 , pp. I 5-I 8 .

Haselberger, L. and J. H. Humphrey (eds) (2006), Imaging Ancient Rome: Documentation - Vizualization - Imagination. Proceedings of the Third Williams Symposium on Classical Architecture Held at the American Academy in Rome, the British School at Rome, and the Deutsches Archäologisches Institut, Rome, 
On May 20-23, 2004, Journal of Roman Archaeology, Supplementary Series 6I, Portsmouth, RI: J. H. Humphrey.

Hinz, W. (I974), 'Tiara', in Paulys Realencyclopädie der classischen Altertumswissenschaft, Suppl. I4, Stuttgart: Alfred Druckenmüller, pp. 786-96.

Hollstein, C. W. (I993), Die stadtrömische Münzprägung der Jahre 78-50 v. Chr. zwischen politischer Aktualität und Familienthematik: Kommentar und Bibliographie, Munich: Herbert Utz.

Hülsen, C. (I902), 'Jahresbericht über neue Funde und Forschungen zur Topographie der Stadt Rom: Neue Reihe I, Die Ausgrabungen auf dem Forum Romanum I898-I902', Mitteilungen des Kaiserlich Deutschen Archäologischen Instituts, Römische Abteilung I7, pp. I-97.

Hülsen, C. (I905), 'Jahresbericht über neue Funde und Forschungen zur Topographie der Stadt Rom: Die Ausgrabungen auf dem Forum Romanum I902-I904', Mitteilungen des Kaiserlich Deutschen Archäologischen Instituts, Römische Abteilung 20, pp. I-II9.

Isager, J. (I986), 'Plinio il Vecchio e le meraviglie di Roma: Mirabilia in terris e Romae miracula nel XXXVI libro della Naturalis Historia', Analecta Romana Instituti Danici I 5, pp. 37-50.

Isager, J. (I99I), Pliny on Art and Society: The Elder Pliny's Chapter on the History of Art, Odense: Odense University Press.

Kay, P. (20I4), Rome's Economic Revolution, Oxford: Oxford University Press.

King, D. (I998), 'Figured supports: Vitruvius' Caryatids and Atlantes', Numismatica e Antichità Classiche 27, pp. 275-305.

Koch, M. (2009), 'Spolia, praeda, manubiae: Zur staatlichen Aneignung fremden Gutes in der lateinischen Literatur', in T. G. Schattner and F. Valdés Fernández (eds), Spolien im Umkreis der Macht: Akten der Tagung in Toledo vom 21 . bis 22. September 2006, Mainz: Philipp von Zabern, pp. I7-32.

Kockel, V. (I995), 'Forum Augustum', in E. M. Steinby (ed.), Lexicon Topographicum Urbis Romae. 2: D-G, Rome: Quasar, pp. 289-95.

König, R. and J. Hopp (eds) (I992), C. Plinius Secundus d. Ä., Naturkunde, Lateinisch-Deutsch, Buch XXXVI, Munich: Artemis and Winkler.

Kränzle, P. (I994), 'Der Fries der Basilica Aemilia', in A. H. Borbein (ed.), Antike Plastik 23, Munich: Hirmer, pp. 93-I30.

Kroll, W. (I95 I), 'Plinius der Ältere', in Paulys Realencyclopädie der classischen Altertumswissenschaft, vol. 2I, Waldsee: Alfred Druckenmüller, pp. 27 I-439.

La Rocca, E. (200I), 'La nuova immagine dei fori imperiali: Appunti in margine agli scavi', $M D A I(R)$ I08, pp. I7I-2I3.

Lanciani, R. (I899), 'Le escavazioni del foro', Bull. Com. Arch. 27, pp. I69-204.

Lanciani, R. (I900), 'Le escavazioni del foro', Bull. Com. Arch. 28, pp. 3-27.

Landwehr, C. (2000), Die römischen Skulpturen von Caesarea Mauretaniae. 2: Idealplastik: Männliche Figuren, Mainz: Philipp von Zabern.

Lesk, A. L. (2007), “"Caryatides probantur inter pauca operum”: Pliny, Vitruvius, and the semiotics of the Erechtheion maidens at Rome', Arethusa 40, pp. 25-42.

Lipps, J. (20I I), Die kaiserzeitliche Basilica Aemilia am Forum Romanum und ihr architektonischer Schmuck, Wiesbaden: Dr. Ludwig Reichert.

Lipps, J. (20I4), 'Bauornamentik und städtebaulicher Kontext,: Die Basilica Aemilia und das Forum Romanum in augusteischer Zeit', in J. Lipps and D. Maschek (eds), Antike Bauornamentik, Grenzen und Möglichkeiten ihrer Erforschung, Bayerische Akademie der Wissenschaften, Kommission zur Erforschung des antiken Städtewesens, Studien zur antiken Stadt I2, Wiesbaden: Dr. Ludwig Reichert, pp. I49-62. 
Maischberger, M. (1997), Marmor in Rom: Anlieferung, Lager- und Werkplätze in der Kaiserzeit, Wiesbaden: Dr. Ludwig Reichert.

Mayhoff, C. (ed.) (I 897), C. Plini Secundi Naturalis Historiae Libri XXXVII: Post Ludovici Iani obitum, recognovit et scripturae discrepantia adiecta. 5: Libri $X X X I-X X X V I I$, Stuttgart: G. B. Teubner (reprint I967).

Meneghini, R. (2009), I Fori Imperiali e i Mercati di Traiano: Storia e descrizione dei monumenti alla luce degli studi e degli scavi recenti, Rome: Liberia dello Stato.

Meneghini, R. and R. Rea (eds) (2014), La biblioteca infinita: I luoghi del sapere nel mondo antico. Published on the Occasion of an Exhibition Held at the Colosseo, Rome, Italy, March I4-October 5, 2014 , Milan: Electa.

Meneghini, R., A. Corsaro and B. Pinna Caboni (2009), 'Il Templum Pacis alla luce dei recenti scavi', in F. Coarelli (ed.), Divus Vespasianus: Il bimillenario dei Flavi, Exhibition, Rome, 27 March-Io January 2010, Milan: Electa, pp. I90-20I.

Möller, L. and M. Vogel (eds) (2007 [1882]), Die Naturgeschichte des Gaius Plinius Secundus, Ins Deutsche übersetzt und mit Anmerkungen versehen von Georg C. Wittstein, rev. edn, Wiesbaden: Marix.

Pensabene, P. (2013), I marmi nella Roma antica, Rome: Carocci.

Platner, S. B. and T. Ashby (I929), A Topographical Dictionary of Ancient Rome, by S. B. Platner, completed and revised by T. Ashby, Oxford: Oxford University Press.

Robert, L. (1963), Noms indigènes dans l'Asie Mineure gréco-romaine, Paris: Maisonneuve.

Rose, C. B. (2002), 'Bilingual Trojan iconography', in A. Rüstem, S. W. Blum, G. Kastl, F. Schweitzer and D. Thumm (eds), Mauerschau: Festschrift für Manfred Korfmann I, Remshalden-Grunbach: Bernhard Albert Greiner, pp. 329-50.

Rose, C. B. (2005), 'The Parthians in Augustan Rome', AJA ro9, pp. 2 I-75.

Schneider, O. (1967), In C. Plini Secundi naturalis historiae libros indices, Hildesheim: Georg Olms.

Schneider, R. M. (1986), Bunte Barbaren: Orientalenstatuen aus farbigem Marmor in der römischen Repräsentionskunst, Worms: Wernersche Verlagsgesellschaft.

Schneider, R. M. (200I), 'Coloured marble: The splendour and power of imperial Rome', Apollo, July, pp. 3-ro.

Schneider, R. M. (2002), 'Nuove immagini del potere romano: Sculture in marmo colorato nell'impero romano', in M. De Nuccio and L. Ungaro (eds), I marmi colorati della Roma imperiale: Rome, Mercati di Traiano, exhibition 28 September 2002-I9 January 2003, Venice: Marsilio, pp. 82-I05.

Schneider, R. M. (2004), 'Nicht mehr Ägypten, sondern Rom: Der neue Lebensraum der Obelisken', in P. C. Bol, G. Kaminski and C. Maderna (eds), Fremdheit Eigenheit: Ägypten, Griechenland und Rom, Austausch und Verständnis, Städel Jahrbuch, n.f. I9, Munich: Prestel, pp. I 55-79.

Schneider, R. M. (2007), 'Friend and foe: The Orient in Rome', in V. Sarkhosh and S. Stewart (eds), The Age of the Parthians, London: I. B. Tauris, pp. 50-86.

Schneider, R. M. (20I2), 'The making of Oriental Rome: Shaping the Trojan legend', in P. Fibiger Bang and D. Kolodziejczyk (eds), Universal Empire: A Comparative Approach to Imperial Culture and Representation in Eurasian History, Cambridge: Cambridge University Press, pp. 76-I 29.

Seiterle, G. (I985), 'Die Urform der phrygischen Mütze', Antike Welt: Zeitschrift für Archäologie und Kulturgeschichte I6(3), pp. 2-I3.

Shatzman, I. (I972), 'The Roman general's authority over booty', Histuria: Zeitschrift für Alte Geschichte 21, pp. 177-205. 
Smith, R. R. R. (20I3), The Marble Reliefs from the Julio-Claudian Sebasteion. Aphrodisias 6: Results of the Excavations at Aphrodisias in Caria by New York University, Darmstadt and Mainz: Philipp von Zabern.

Snodgrass, A. M. (2006), 'Separate tables? A story of two traditions within one discipline', in A. M. Snodgrass, Archaeology and the Emergence of Greece, Ithaca: Cornell University Press, pp. I05-13.

Spannagel, M. (I999), Exemplaria Principis: Untersuchungen zu Entstehung und Ausstattung des Augustusforums, Heidelberg: Archäologie und Geschichte.

Spivey, N. and M. Squire (2004), Panorama of the Classical World, London: Thames \& Hudson.

Steinby, E. M. (I993), 'Basilica Aemilia', in E. M. Steinby (ed.), Lexicon Topographicum Urbis Romae. I: A-C, Rome: Quasar, pp. 167-8.

Strocka, V. M. (2007), 'Vergils tibicenes', Gymnasium: Zeitschrift für Kultur der Antike und Humanistische Bildung I I4, pp. 523-33.

Swetnam-Burland, M. (201 5), Egypt in Italy: Visions of Egypt in Roman Imperial Culture, Cambridge: Cambridge University Press.

Tarpin, M. (2009), 'Les manubiae dans la procédure d'appropriation du butin', in M. Coudry and M. Humm (eds), 'Praeda': Butin de guerre et société dans la Rome républicaine/Kriegsbeute und Gesellschaft, Stuttgart: Franz Steiner, pp. $8 \mathrm{I}-\mathrm{IO} 2$.

Ungaro, L. (ed.) (2007), Il Museo dei Fori Imperiali nei Mercati di Traiano, Milan: Electa.

Vaglieri, D. (I903), 'Gli scavi nel Foro Romano', Bull. Com. Arch. 3 I, pp. 3-239.

Wallace-Hadrill, A. (2007), "Mutatas formas": The Augustan transformation of Roman knowledge', in K. Galinsky (ed.), The Cambridge Companion to the Age of Augustus, Cambridge: Cambridge University Press, pp. 55-84.

Wilhelm, R. M. (I988), 'Cybele, the Great Mother of Augustan order', Vergilius: The Journal of the Vergilian Society of America 34, pp. 77-IoI.

Wirsching, A. (2013), Obelisken transportieren und aufrichten in Ägypten und in Rom, Mit einem Exkurs zu den Memnonkolossen, $3^{\text {rd }}$ rev. edn, Norderstedt: Books on Demand.

Wittke, A.-M., E. Olshausen and R. Szydlak (eds) (2007), Historischer Atlas der antiken Welt: Der Neue Pauly, Suppl. 3, Stuttgart and Weimar: J. B. Metzler.

Wrigley, R. (I997), 'Transformations of a revolutionary emblem: The Liberty Cap in the French Revolution', French History I I, pp. I 3 I-69.

Zanker, P. (I 968), Forum Augustum: Das Bildprogramm, Tübingen: Wasmuth. 